OPEN ACCESS

Edited by:

Jia-bo Wang,

Fifth Medical Center of the PLA

General Hospital, China

Reviewed by:

Wei Sheng,

Fudan University, China

Qin Wan Huang,

Chengdu University of Traditional

Chinese Medicine, China

${ }^{*}$ Correspondence:

Cheng Zhao

chengzhao_79@163.com

Youhua Wang

doctorwyh@163.com

Specialty section:

This article was submitted to

Ethnopharmacology,

a section of the journa

Frontiers in Pharmacology

Received: 16 April 2020

Accepted: 30 July 2020

Published: 03 September 2020

Citation:

Peng L, Dong Y, Fan H, Cao M, Wu Q, Wang Y, Zhou C, Li S, Zhao C and Wang Y (2020) Traditional Chinese

Medicine Regulating

Lymphangiogenesis:

A Literature Review.

Front. Pharmacol. 11:1259. doi: 10.3389/fphar.2020.01259

\section{Traditional Chinese Medicine Regulating Lymphangiogenesis: A Literature Review}

\author{
Longping Peng ${ }^{1}$, Yidan Dong ${ }^{1}$, Hua Fan ${ }^{1}$, Min $\mathrm{Cao}^{1}$, Qiong Wu ${ }^{1}$, Yi Wang ${ }^{1}$, Chang Zhou ${ }^{1}$, \\ Shuchun $\mathrm{Li}^{1}$, Cheng Zhao ${ }^{2 *}$ and Youhua Wang ${ }^{1 *}$ \\ ${ }^{1}$ Cardiovascular Department, Longhua Hospital, Shanghai University of Traditional Chinese Medicine, Shanghai, China, \\ 2 Vascular Disease Department, Shanghai Traditional Chinese Medicine Integrated Hospital, Shanghai University of Traditional \\ Chinese Medicine, Shanghai, China
}

Lymphatic vessels, as an important part of the lymphatic system, form a fine vascular system in humans and play an important role in regulating fluid homeostasis, assisting immune surveillance and transporting dietary lipids. Dysfunction of lymphatic vessels can cause many diseases, including cancer, cardiovascular diseases, lymphedema, inflammation, rheumatoid arthritis. Research on lymphangiogenesis has become increasingly important over the last few decades. Nevertheless, the explicit role of regulating lymphangiogenesis in preventing and treating diseases remains unclear owing to the lack of a deeper understanding of the cellular and molecular pathways of the specific and tissue-specific changes in lymphangiopathy. TCM, consisting of compound extracted from TCM, Injections of single TCM and formula, is an important complementary strategy for treating disease in China. Lots of valuable traditional Chinese medicines are used as substitutes or supplements in western countries. As one of the main natural resources, these TCM are widely used in new drug research and development in Asia. Moreover, as a historical and cultural heritage, TCM has been widely applied to clinical research on lymphangiogenesis leveraging new technologies recently. Available studies show that TCM has an explicit effect on the regulation of lymphatic regeneration. This review aims to clarify the function and mechanisms, especially the inhibitory effect of TCM in facilitating and inhibiting lymphatic regeneration.

Keywords: lymphangiogenesis, traditional Chinese medicine, inhibitory factor, facilitating factor, promoting factor

\section{INTRODUCTION}

The lymphatic vasculature, the precollectors and collecting vessels, absorbed interstitial fluid, and solutes from the extracellular space, is composed of monolayer overlapping LECs, which are derived mainly from the vascular endothelial cells in the process of embryonic development (Vaahtomeri et al., 2017). Lymphangiogenesis is the production of the new lymphatic vasculature on the basis of initial lymphatic vessel (Stacker et al., 2014). Dysfunction of lymphatic vessels can cause many diseases, including cancer, cardiovascular diseases, lymphedema, inflammation, rheumatoid arthritis 
(Kunstfeld et al., 2004; Alitalo et al., 2005; Kajiya and Detmar, 2006; Polzer et al., 2008; Aspelund et al., 2016). For example, numerous works on xenogeneic tumor transplantation models in mice have demonstrated that targeting the VEGFC-VEGFR3 and VEGFD-VEGFR3 axis can inhibit tumor lymphangiogenesis, lymphadenopathy, and lymph node metastasis (Stacker et al., 2001; Karpanen et al., 2001; He et al., 2002; Achen et al., 2005; He et al., 2005; Lin et al., 2005; Alitalo, 2011). Tumor lymphangiogenesis may be a useful prognostic indicator for human melanoma (35138) and other human tumor lymph node metastasis, which is consistent with the concept that clinically targeted tumor lymphangiogenesis may limit lymph node metastasis and potential distant organ metastasis (Dadras et al., 2003; Dadras et al., 2005; Stacker et al., 2014). But so far, most research of therapeutic lymphangiogenesis focused on the delivery of the VEGFC gene or the VEGFC protein, which stimulates lymphangiogenesis in its pro-teolytically processed mature form (Joukov et al., 1997; Jha et al., 2017). As early as 40 years ago, cardiac lymph function has been confirmed to alter in cardiovascular disease (Bradham and Parker, 1973). However, only in the past few years, the first published research on the occurrence and role of cardiac lymphatic remodeling in cardiovascular diseases, including myocardial infarction (MI) and chronic heart failure (HF) (Ishikawa et al., 2007; Cui, 2010; Kholová et al., 2011; Klotz et al., 2015; Aspelund et al., 2016; Henri et al., 2016; Dashkevich et al., 2016; Randolph et al., 2017). Early clinical trials of cardiac lymphatics were stopped due to catheter problems, and no data are available on the potential effects on cardiac lymphatics, myocardial edema, or myocardial fibrosis in these patients (Brakenhielm and Alitalo, 2019).

In this review, we aim to provide researchers with the latest advances in the regulation of lymphangiogenesis and the effects and mechanisms of TCM in regulating lymphangiogenesis. TCM, an essential part of traditional culture in China, has ageold history of thousands of years, with both a unique theoretical system and rich clinical experience. In other countries, TCM is often treated as an alternative or complementary medicine, due to a lack of quantitative and objective evaluation criteria. However, TCM has gained growing popularity in many developed countries, such as the United States and Australia. Significantly, some

\footnotetext{
Abbreviations: TCM, Traditional Chinese Medicine; ART, artemisinin; DHA, dihydroartemisinin; GS-Rg3, 20(R)-ginsenoside Rg3; GS-Rh2, ginsenoside Rh2; CPT, cryptotanshinone; GS-Rg1, Ginsenoside Rg1; HIF-1, Hypoxia-inducible factor-1; Ang-1/2, Angopoietin-1/2; MMP-9, matrix metalloproteinase-9; VEGF, vascular endothelial growth factor; LECs, lymphatic endothelial cells; LY, lymphangiogenesis; MOA, mechanism of action; FGF-2, fibroblast growth factor-2; IGF-1/2, Insulin-like growth factor-1/2; PDGF-BB, platelet derived growth factor-BB; HGF, hepatocyte growth factor; TNF, tumor necrosis factor; IL, interleukin; CLEC14A, C-type lectin family 14 member A; ET-1, Endothelin-1; TSP-1, Thrombospondin-1; TGF- $\beta 1$, Transforming Growth Factor; IFN- $\gamma$, Interferon; BMP2, Bone morphogenetic protein; NCTD, Norcantharidin; PNS, Total saponins of panaxnotoginseng; DHJST, DuHuoJiShengTang; FJHQ, FangjiHuangqi; VRIN, VEGFR3-mediated immune-nanoemulsion of ginsenoside Rg3; GSPP, Gekko Sulfated Glycopeptide; HDLEC, human dermal lymphatic endothelial cells; MLVD, micro lymphatic vessel density; RKY, RuKangYin; JFK, JinFuKang; NSCLC, non-small cell lung cancer; JG-DS, Jinlongshe Granule drug-containing serum; LVD, lymphatic vessel density; HDW, Hedyotis diffusa Willd; EEHDW, Ethanol extract of HDW; PZH, Pien Tze Huang.
}

patients prefer to reduce the use of Western medicine suggested by current medical guidelines when the TCM can control the disease (Guo et al., 2013). Available research has demonstrated that TCM can affect lymphangiogenesis in the treatment of different diseases such as cancer (Dai et al., 2017), inflammatory diseases (Liang et al., 2016; Li et al., 2016), rheumatoid arthritis (Chen et al., 2016), lymphedema (Wang et al., 2017). Although TCM plays a role in regulating lymphangiogenesis, their molecular targets are largely unknown. Finding their binding targets would help uncover the mechanisms by which TCM modulates lymphangiogenesis. Much of the research in the growth of lymphatic vessels in the past decades have verified the regulatory effect of TCM. Work on the mechanisms and effects of TCM is still at an early stage. However, all relevant publications indicate that TCM's potential to regulate lymphangiogenesis deserves further study.

\section{AN OVERVIEW OF RELEVANT TCM}

Current research indicates that TCM has certain regulatory effects on lymphangiogenesis during disease pathology, which is helpful for the treatment of diseases. TCM is one of the oldest treatments, mainly comprising natural medication (also called Chinese herbal medicine), physiotherapy (e.g., TuiNa, QiGong), acupuncture (Tang et al., 2008). Chinese herbal medicine-an under developed biological resource-is important for drug discovery and development ( $\mathrm{Li}$ and Vederas, 2009). As an example, DHA, artemether and artesunate, the derivative of artemisinin, has used clinically for the treatment of cerebral malaria and falciparum malaria with good curative effect (Arinaitwe et al., 2009; Lisewski et al., 2014; Wang et al., 2015).

Chinese herbal medicine covers single chinese herbal, effective extraction ingredients of single TCM and Chinese medicine formulas. Available evidence suggest that some TCM extractions, such as ART (Wang J. et al., 2008), DHA (Wang et al., 2007), GS-Rg3 (Li et al., 2009; Dai et al., 2014), GS-Rh2 (Wang Q et al., 2008), CPT (Luo et al., 2011), $\beta$-elemene (Yan et al., 2014), curcumin (Wang et al., 2015), and norcantharidin (Liu et al., 2012), have a potent lymphangiogenesis regulatory effect and may alter the disease course. Here, we provide the structure of related compounds from single TCMs that regulate lymphangiogenesis (Figure 1).

It is an important part of the TCM theory, and an important embodiment of TCM theory used in clinical practice. In the current clinical treatment, the application of Chinese herb recipe is extensive, and it still has more obvious advantages than single Chinese herbal or the monomer from Chinese herbal. Interestingly, studies show that some TCM formulas can effectively regulate lymphangiogenesis.

Currently, except for a few studies involving HIF-1, Ang-1/2, and MMP-9. Others are mainly focused on the effects of TCM in regulating lymphangiogenesis in cancer, and the mechanistic research focuses on VEGF/LECs. In the pathological progress of various diseases, such as lymphedema, cardiovascular diseases, and atherosclerosis, there is still large space to explore the effects and mechanisms of TCM on lymphangiogenesis. 

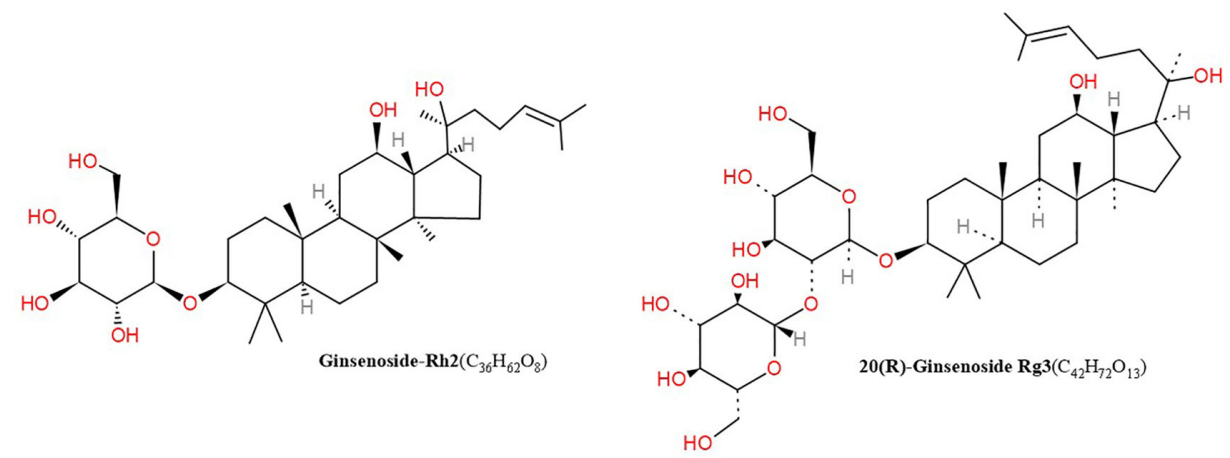<smiles>CCCCC(=O)CC(=O)C=Cc1ccc(O)c(OC)c1</smiles>

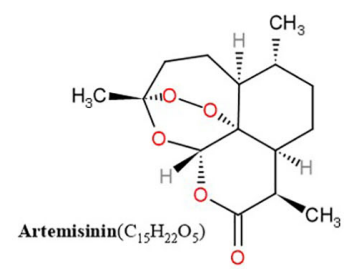

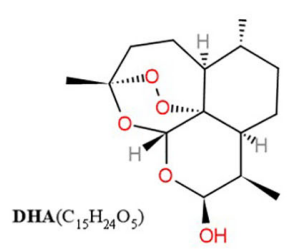

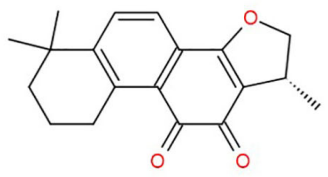

Cryptotanshinone $\left(\mathrm{C}_{19} \mathrm{H}_{20} \mathrm{O}_{3}\right)$

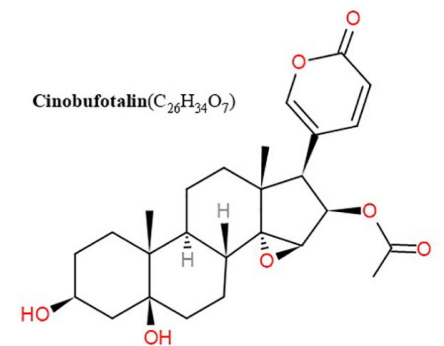

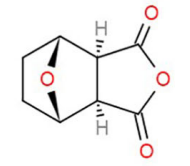

Norcantharidin $\left(\mathrm{C}_{8} \mathrm{H}_{8} \mathrm{O}_{4}\right)$

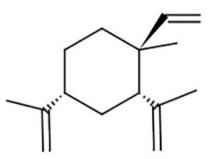

$(-)-\beta$-elemene $\left(\mathrm{C}_{15} \mathrm{H}_{24}\right)$

FIGURE 1 | Structures of artemisinin, DHA, cryptotanshinone, cinobufotalin, norcantharidin, $\beta$-elemene, GS-Rh2, ginsenoside Rg3 (GS-Rg3), curcumin.

\section{REGULATORY FACTORS OF LYMPHANGIOGENESIS}

The lymphatic vessels are crucial for assisting immune function, regulating tissue fluid homeostasis, and accelerating the absorption of dietary fats. The growth of lymphatic vessels occur during wound healing, embryonic development, and under pathological conditions of different diseases, including cardiovascular diseases, cancer, obesity, hypertension, inflammatory diseases, lymphedema, and atherosclerosis. Nevertheless, the molecular mechanisms regulating the growth of lymphatic vessels are far less understood. Certainly, our knowledge of the effects and regulatory mechanisms of the lymphatic vascular system will give rise to creative and crucial insights in biology and clinical medicine. Lymphangiogenesis, the growth of lymphatic vessels, has captured growing attention in the past few decades, mainly thanks to advances in the discovery of regulatory factors and markers particular to the lymphatic endothelium. This promoted the research on regulation of lymphangiogenesis by TCM.

Much of the research has demonstrated that the development of lymphangiogenic factors, lymphangiogenesis, and the remodel of lymphatic vessels can associate with some progression of the disease. For example, Lymphatic vessels modulate the immune response of cancer and restrict metastasis, providing targets for cancer treatment. Importantly, lymphangiogenesis exists in tissues not only during the metastasis of the tumor but also in inflammation and wound healing. Consequently, the organization of Lymphatic factors makes it possible to target lymphatic vessels in the disease. Then, we summarize the latest progress that has exceedingly advanced our understanding of the factors and mechanisms of lymphangiogenesis, including promoters (Table 1 and inhibitors Table 2). 


\section{TCM FOR FACILITATING LYMPHANGIOGENESIS (TABLE 3)}

Compared with the lymphangiogenesis inhibition of TCM, the research on promoting lymphangiogenesis by TCM is relatively limited until now. Only one TCM monomer and two formulas work.

GS-Rg1 is one of the most active ingredients extracted mainly from panax ginseng (Figure 2). Yu et al. observed the effect of GSRg1 on the lymphatic transport of silica during experimental silicosis. It was found that GS-Rg1 increases the density of pulmonary LVD and facilitates lymphangiogenesis by enhancing the protein and mRNA expression of VEGF-C and VEGFR-3 (Yu et al., 2016).

TABLE 1 | Lymphangiogenesis (LY) facilitating factors with the function.

\begin{tabular}{|c|c|c|}
\hline $\begin{array}{l}\text { Facilitating } \\
\text { factor of LY }\end{array}$ & Mechanism of action (MOA) & References \\
\hline \multirow[t]{5}{*}{ VEGF } & $\begin{array}{l}\text { Binding specific receptors to } \\
\text { stimulate lymphangiogenesis }\end{array}$ & (Kunstfeld et al., 2004). \\
\hline & $\begin{array}{l}\text { VEGF-A binds to VEGFR-1/fms-like } \\
\text { tyrosine kinase } 1 \text { (FLT-1) }\end{array}$ & (Joukov et al., 1996). \\
\hline & $\begin{array}{l}\text { VEGFR-2/human kinase insert } \\
\text { domain receptor (KDR) }\end{array}$ & (Achen et al., 1998). \\
\hline & $\begin{array}{l}\text { VEGF-C and VEGF-D bind to } \\
\text { VEGFR-3/FLT4, and upon } \\
\text { proteolytic processing can bind to } \\
\text { VEGFR-2 }\end{array}$ & (Jeltsch et al., 1997). \\
\hline & $\begin{array}{l}\text { Activating intracellular signaling } \\
\text { pathways such as map kinases } \\
\text { Erk1/2 and Akt }\end{array}$ & (Veikkola et al., 2001) \\
\hline FGF-2 & $\begin{array}{l}\text { Activating FGFR-1, induce } \\
\text { lymphangiogenesis direatly } \\
\text { Facilitating the increase of VEGF-C/ } \\
\text { D and stimulate lymphangiogenesis }\end{array}$ & $\begin{array}{l}\text { (Kubo et al., 2002). } \\
\text { (Chang et al., 2004). } \\
\text { (Cao et al., 2012). } \\
\text { (Kazenwadel et al., } \\
\text { 2012). }\end{array}$ \\
\hline IGF-1/IGF-2 & $\begin{array}{l}\text { Combined with IGFR to induce } \\
\text { lymphangiogenesis directly }\end{array}$ & $\begin{array}{l}\text { (Björndahl et al., 2005). } \\
\text { (Li et al., 2013). }\end{array}$ \\
\hline & $\begin{array}{l}\text { Through other growth factor } \\
\text { receptor systems induces } \\
\text { lymphangiogenesis indirectly }\end{array}$ & (Morgillo et al., 2013) \\
\hline \multirow[t]{2}{*}{ PDGF-BB } & $\begin{array}{l}\text { Binding to PDGF-BB receptor to } \\
\text { induces lymphatic vessel growth } \\
\text { directly }\end{array}$ & $\begin{array}{l}\text { (Eriksson et al., 2003). } \\
\text { (Cao et al., 2004). }\end{array}$ \\
\hline & $\begin{array}{l}\text { Activating intracellular signaling } \\
\text { pathways such as map kinases } \\
\text { Erk1/2 and Akt }\end{array}$ & $\begin{array}{l}\text { (Schoppmann et al., } \\
\text { 2013) }\end{array}$ \\
\hline \multirow[t]{2}{*}{$\begin{array}{l}\text { Angopoietin } \\
\text { (Ang) }\end{array}$} & $\begin{array}{l}\text { Ang- } 1 \text { induces Tie- } 2 \\
\text { phosphorylation in LEC and } \\
\text { promotes lymphatic budding and } \\
\text { growth }\end{array}$ & (D’Amico et al., 2014). \\
\hline & $\begin{array}{l}\text { Ang-2,Ang- } 3 \text { and Ang- } 4 \text { Promotes } \\
\text { lymphangiogenesis in wound healing } \\
\text { models, with the specific } \\
\text { mechanism is not clear }\end{array}$ & $\begin{array}{l}\text { (Tammela et al., 2005). } \\
\text { (Morisada et al., 2005). } \\
\text { (Kim et al., 2007) }\end{array}$ \\
\hline \multirow[t]{2}{*}{ HGF } & $\begin{array}{l}\text { Binding to c-Met to increase } \\
\text { expression of podoplanin and LYVE- } \\
\text { 1, induces lymphatic vessel growth } \\
\text { directly }\end{array}$ & $\begin{array}{l}\text { (Saito et al., 2006). } \\
\text { (Jiang et al., 1999). }\end{array}$ \\
\hline & $\begin{array}{l}\text { Through VEGFR-3 promotes } \\
\text { Iymphangiogenesis Indirectly }\end{array}$ & $\begin{array}{l}\text { (Cao et al., 2006). } \\
\text { (Zhang et al., 2015) }\end{array}$ \\
\hline
\end{tabular}

(Continued)
TABLE 1 | Continued

\begin{tabular}{|c|c|c|}
\hline $\begin{array}{l}\text { Facilitating } \\
\text { factor of LY }\end{array}$ & Mechanism of action (MOA) & References \\
\hline TNF & $\begin{array}{l}\text { TNF- } \alpha / L T-\alpha, \text { up-regulates the } \\
\text { protein expression of VEGF-D } \\
\text { through the ERK } 1 / 2-A P 1 \text { pathway, } \\
\text { and upregulates VEGF-C expression } \\
\text { through macrophages }\end{array}$ & $\begin{array}{l}\text { (Mohamadzadeh et al., } \\
\text { 1998). } \\
\text { (Baluk et al., 2005). } \\
\text { (Hong et al., 2016). } \\
\text { (Hjelmström et al., } \\
\text { 2000). } \\
\text { (Mounzer et al., 2010). } \\
\text { (Cuff et al., 1998). } \\
\text { (Ristimäki et al., 1998). } \\
\text { (Sacca et al., 1998). } \\
\text { (Furtado et al., 2007) }\end{array}$ \\
\hline IL & $\begin{array}{l}\text { IL-1 } 1 \beta \text {, increases the expression of } \\
\text { VEGF-C/D in macrophages } \\
\text { IL-33, through the ST2/TRAF6- } \\
\text { mediated Akt/eNOS/NO signaling } \\
\text { pathway }\end{array}$ & $\begin{array}{l}\text { (Baluk et al., 2013). } \\
\text { (Han et al., 2017) }\end{array}$ \\
\hline Adenosine & $\begin{array}{l}\text { Stimulating lymphangiogenesis } \\
\text { through the involvement of } \\
\text { macrophages }\end{array}$ & (Lenoir et al., 2014) \\
\hline Netrin-4 & $\begin{array}{l}\text { Activating small GTPases and Src } \\
\text { family kinases/FAK, and down- } \\
\text { regulating tight junction proteins } \\
\text { Activating p42/p44 MAPkinase, Akt/ } \\
\text { PI3kinase and mTor signaling } \\
\text { pathways }\end{array}$ & $\begin{array}{l}\text { (Sleeman and Thiele, } \\
\text { 2009). } \\
\text { (Larrieu-Lahargue } \\
\text { et al., 2010) }\end{array}$ \\
\hline CLEC14A & $\begin{array}{l}\text { Interacting with VEGF-3 to regulate } \\
\text { the expression and Signal } \\
\text { Transduction of VEGFR-2 and } \\
\text { VEGFR-3 }\end{array}$ & (Lee et al., 2017) \\
\hline Adrenomedullin & $\begin{array}{l}\text { Activating Notch signaling pathway } \\
\text { and transactivating VEGFR-2 }\end{array}$ & $\begin{array}{l}\text { (Nicoli et al., 2008). } \\
\text { (Yurugi-Kobayashi } \\
\text { et al., 2006). } \\
\text { (Guidolin et al., 2008) }\end{array}$ \\
\hline ET-1 & $\begin{array}{l}\text { Binding to ETBR, stimulating the } \\
\text { expression of HIF-1a, up-regulating } \\
\text { the expression of VEGF-C, VEGFR- } \\
3 \text { and VEGF-A }\end{array}$ & $\begin{array}{l}\text { (Spinella et al., 2009). } \\
\text { (Irigoyen et al., 2007). } \\
\text { (Ota et al., 2007). } \\
\text { (Schoppmann et al., } \\
\text { 2006). } \\
\text { (Katsuta et al., 2005). }\end{array}$ \\
\hline
\end{tabular}

TABLE 2 | Lymphangiogenesis inhibitory factors with the functional mechanisms.

\begin{tabular}{|c|c|c|}
\hline $\begin{array}{l}\text { Inhibitory } \\
\text { factor of } \\
\text { LY }\end{array}$ & Mechanism of action (MOA) & Ref \\
\hline TSP-1 & $\begin{array}{l}\text { Linked with CD36 in macrophages to } \\
\text { reduce the expression levels of VEGF-C } \\
\text { and VEGF-D }\end{array}$ & (Cursiefen et al., 2011). \\
\hline TGF- $\beta 1$ & $\begin{array}{l}\text { TGF- } \beta 1 \text {, reducing the recruitment, } \\
\text { proliferation, and tubule formation of LEC }\end{array}$ & $\begin{array}{l}\text { (Oka et al., 2008). } \\
\text { (Clavin et al., 2008). } \\
\text { (Avraham et al., 2010). }\end{array}$ \\
\hline IFN- $\gamma$ & $\begin{array}{l}\text { Through serial events of signaling by } \\
\text { IFN- } \gamma \text { via IFNGR-1 and/or IFNGR-2, JAK, } \\
\text { and STAT-1 phosphorylation, causes the } \\
\text { downregulation of Prox-1, LYVE-1, and } \\
\text { podoplanin in LECs }\end{array}$ & (Kataru et al., 2011). \\
\hline
\end{tabular}

BMP2

Strongly inhibits the expression of PROX1, the master regulator for the lymphatic fate, in a SMAD-dependent and miRNA-dependent manner

Endostatin Decreasing the VEGF-C levels 
TABLE 3 | TCM for facilitating lymphangiogenesis.

\begin{tabular}{|c|c|c|c|c|c|}
\hline Drug & Model & $\begin{array}{l}\text { Dosage and Route of } \\
\text { administration }\end{array}$ & Mechanism & $\begin{array}{l}\text { The herbal composition } \\
\text { (including the scientific name) }\end{array}$ & Ref \\
\hline GS-Rg1 & $\begin{array}{l}\text { Male Spraguee } \\
\text { Dawley (SD) rats }\end{array}$ & $\begin{array}{l}10 \mathrm{mg} / \mathrm{kg} / \text { day } \\
\text { Gavage administration }\end{array}$ & $\begin{array}{l}\text { Enhancing the } \\
\text { expression levels of } \\
\text { VEGF-C and VEGFR-3 }\end{array}$ & $\begin{array}{l}\text { Extracted from panax - ginseng (Panax ginseng } \\
\text { C.A.Mey.) }\end{array}$ & (Yu et al., 2016) \\
\hline PNS & $\begin{array}{l}\text { 1) The transgenic } \\
\text { zebrafish line (fli1: } \\
\text { egfp; gata1:dsred) } \\
\text { 2) A murine LEC cell } \\
\text { line established from } \\
\text { Freund's adjuvant- } \\
\text { induced benign } \\
\text { lymphangiomas }\end{array}$ & $\begin{array}{l}10,50,100 \mu \mathrm{M} \\
\text { Immersion administration }\end{array}$ & $\begin{array}{l}\text { Up-regulating VEGF-C } \\
\text { expression and } \\
\text { activation of ERK1/2, } \\
\text { PI3K and P38MAPK } \\
\text { signaling }\end{array}$ & $\begin{array}{l}\text { Extracted from Panaxnotoginseng (Panax } \\
\text { notoginseng (Burkill) F. H. Chen ex C. H.) }\end{array}$ & (Li et al., 2016) \\
\hline DHJST & $\begin{array}{l}\text { 1) The lines of TNF } \\
\text { transgenic mice } \\
\text { 2) The transgenic } \\
\text { zebrafish line (fli1: } \\
\text { egfp; gata1:dsRed) }\end{array}$ & $\begin{array}{l}\text { 1) } 12 \mathrm{~g} / \mathrm{kg} \\
\text { Gavage administration } \\
\text { 2) } 10,30,100 \mu \mathrm{g} / \mathrm{mL} \\
\text { ImmersionAdministration }\end{array}$ & Not mentioned & $\begin{array}{l}\text { Composed of Radix Angelicae Pubescentis, Herba } \\
\text { Taxilli, Radix Acanthopanacis Bidentatae, Herba } \\
\text { Asari, Radix Gentianae Macrophyllae, Cortex } \\
\text { Cinnamomi, Eucommia, Rhizoma Chuanxiong, Radix } \\
\text { Saposhnikoviae, Radix Saposhnikoviae, liquorice, } \\
\text { angelica, peony, Rehmannia, Ginseng, and poria }\end{array}$ & (Chen et al., 2016) \\
\hline FJHQ & $\begin{array}{l}\text { 1) The lines of TNF } \\
\text { transgenic mice } \\
\text { 2) The transgenic } \\
\text { zebrafish line (fli1: } \\
\text { egfp; gata1:dsRed) }\end{array}$ & $\begin{array}{l}\text { 1) } 12 \mathrm{~g} / \mathrm{kg} \\
\text { Gavage administration } \\
\text { 2) } 10,30,100 \mu \mathrm{g} / \mathrm{mL} \\
\text { Immersion Administration }\end{array}$ & Not mentioned & $\begin{array}{l}\text { Composed of Stephania tetrandra S.Moore, } \\
\text { Astragalus membranaceus (Fisch.) Bunge., } \\
\text { Atractylodes macrocephala Koidz. Glycyrrhiza } \\
\text { uralensis Fisch }\end{array}$ & (Wang et al., 2017) \\
\hline
\end{tabular}

PNS used as a drug in China for treating cardiovascular and cerebrovascular diseases, are a mixture extracted from Panaxnotoginseng (Figure 2). When studied the mechanism and the effect of PNS on the growth of lymphatic vessels, it was found that PNS activates the growth of lymphatic vessels both in vitro and in vivo via upregulating the expression of VEGF-C and activation of ERK1/2, PI3K, and P38MAPK signaling. These findings suggest that PNS might be a suitable and promising therapeutic agent for the treatment of lymphatic system impairment-related disease (Li et al., 2016).

TCM formula-DHJST, widely used in China to treat rheumatoid arthritis, is a proprietary Chinese medicine. Two animal models, zebrafish and mice, were used to study the effect of DHJST on lymphangiogenesis. The zebrafish research showed that DHJST facilitated the formation of Lymphatic vessels. Furthermore, DHJST promotes lymphangiogenesis and the lymphatic drainage function of mice (Chen et al., 2016). Interestingly, in order to study the mechanism of FJHQ Decoction treats for joint swelling, Wang et al. also used two animal models, mice (TNF- $\alpha$ transgenic mice) and zebrafish. The results show that FJHQ decoction promoted lymphatic drainage and lymphangion genesis to alleviate joint swelling (Wang et al., 2017).

Although the TCM theory of Chinese herb recipe lacks synchronous TCM pathology or pathogenesis research, there are already international successful examples of Chinese herb recipe as a drug for modern medical pharmacology research, and there are efforts to furtherly introduce it into the mainstream of science (Normile, 2003). Chinese herb recipe is worth researching.

\section{TCM FOR INHIBITING LYMPHANGIOGENESIS}

Lymphangiogenic plays an important role in the pathology of disease. For instance, lymphatic factors (like VEGF-A and
VEGFC) can bring about tumor metastasis and spread in mouse cancer models (Tobler and Detmar, 2006). In addition, the inhibitory effect of TCM on lymphangiogenesis is being explored in vivo and in vitro to access its clinical value.

\section{Extracts of Single TCM (Table 4)}

ART, extracted from the Chinese herb Artemisia annua L, is a novel effective antimalarial drug. Experimental analyses have revealed that ART can downregulate the level of VEGF-C and reduce lymphangiogenesis in in vivo and in vitro (Wang J. et al., 2008). Besides, DHA, extracted from Chinese plant artemisinin for the first time, is a semisynthetic agent. DHA dose-dependently inhibited the migration and formation of LECs and upregulated the mRNA level of the proapoptotic gene bax but significantly downregulated the mRNA expression of antiapoptotic bcl-2. What's more, DHA could apparently attenuate the mRNA and protein expressions of VEGFR-3/Flt-4 (Wang et al., 2007), which suggest that DHA might be a candidate as an anti-lymphangiogenesis inhibitor.

In mice with transplanted-tumor via inoculating S180 cells under skin, administration of GS-Rh2 inhibited tumor growth and reduced LVD, indicating that the expression of junction adhesion molecule was weakened and that the lymphangiogenesis in xenograft inhibited after treatment with GS-Rh2 (Wang Q. et al., 2008) (Figure 2). Dai et al. prepared the VRIN to investigate its effect on the growth and lymphangiogenesis of gastric cancer in vivo (Figure 2). The results show that VRIN can suppress the growth and lymphatic metastasis of human gastric cancer cell transplantation tumors in nude mice by downregulating VEGF-C expressions (Dai et al., 2014). Using LECs from healthy pig duct, Li et al. found that GS-Rg3 could induce the apoptosis of LECs and evidently inhibit the migration and proliferation of LECs, and the effects were dose-dependent ( $\mathrm{Li}$ et al., 2009). Noteworthy that the mechanism of GS-Rg3's effect on LECs needs further study. 
TABLE 4 | TCM for inhibiting lymphangiogenesis (extracts of single TCM).

\begin{tabular}{|c|c|c|c|}
\hline Drug & Model & $\begin{array}{l}\text { Dosage and route of } \\
\text { administration }\end{array}$ & Mechanism \\
\hline ART (Wang J. et al., 2008) & $\begin{array}{l}\text { 1) Specific pathogen-free female } \\
\text { C57BL/6 mice } \\
\text { 2) Mouse Lewis lung carcinoma } \\
\text { cells }\end{array}$ & $\begin{array}{l}\text { 1) } 50 \mathrm{mg} / \mathrm{kg} \text { daily } 2 \text { weeks } \\
\text { 2) } 20 \mu \mathrm{M} / 24 \mathrm{~h} \\
\text { Oral//mmersion administration }\end{array}$ & Downregulating the level of VEGF-C \\
\hline DHA (Wang et al., 2007) & Murine LECs & $\begin{array}{l}2.5,10 \mu \mathrm{g} / \mathrm{mL} \\
\text { Immersion administration }\end{array}$ & $\begin{array}{l}\text { 1) Inhibiting the migration and formation of LECs } \\
\text { 2) Attenuating the mRNA and protein levels of VEGFR-3/Flt-4. }\end{array}$ \\
\hline $\begin{array}{l}\text { GS-Rh2 (Wang Q. et al., } \\
\text { 2008) }\end{array}$ & Transplanted-tumor mice & $\begin{array}{l}20 \mathrm{mg} / \mathrm{kg} \\
\text { Gavage administration }\end{array}$ & Down-regulating the expression of the junction adhesion molecul \\
\hline VRIN (Dai et al., 2014) & $\begin{array}{l}\text { Gastric cancer model in nude } \\
\text { mice }\end{array}$ & $\begin{array}{l}1 \mathrm{mg} / \mathrm{kg} 0.1 \mathrm{mg} / \mathrm{kg} \\
\text { Tail vein injection }\end{array}$ & Down regulating the expression of VEGF-C \\
\hline GS- Rg3 (Li et al., 2009) & $\begin{array}{l}\text { LECs which ducted from healthy } \\
\text { pig }\end{array}$ & $\begin{array}{l}10,20,30,50 \mu \mathrm{g} / \mathrm{mL} \\
\text { Immersion administration }\end{array}$ & Inducing LECs apoptosis \\
\hline $\begin{array}{l}\beta \text {-Elemene (Yan et al., } \\
\text { 2014) }\end{array}$ & $\begin{array}{l}\text { 1) Human gastric cancer cells } \\
\text { MKN-45 } \\
\text { 2) Human gastric cancer in nude } \\
\text { mice }\end{array}$ & $\begin{array}{l}25,50,100 \mathrm{mg} / \mathrm{kg} \\
\text { Oral administration }\end{array}$ & Not specific \\
\hline Gecko (Liu et al., 2008) & $\begin{array}{l}\text { 1) The transplanted tumor model } \\
\text { of the mouse S180 sarcoma } \\
\text { 2) Human esophageal carcinoma } \\
\text { cells }\end{array}$ & $\begin{array}{l}13.5,9,4.5 \mathrm{~g} / \mathrm{kg} \\
\text { Oral administration }\end{array}$ & Down regulating protein expression of VEGF-C and bFGF \\
\hline $\begin{array}{l}\text { Gecko powder (Zhang } \\
\text { et al., 2011) }\end{array}$ & BALB/c tumor-bearing mice & $1.2 \mathrm{~g} / \mathrm{kg}$ Gavage administration & Affecting the expression of VEGF-C and not specific \\
\hline GSPP (Ding et al., 2016) & $\begin{array}{l}\text { 1) Human LECs } \\
\text { 2) Nude mice models }\end{array}$ & $\begin{array}{l}\text { 1) } 10 / 100 \mu \mathrm{g} / \mathrm{mL} \text { Immersion } \\
\text { administration } \\
\text { 2) } 200 \mathrm{mg} / \mathrm{kg} / \mathrm{d} \text { Intraperitoneal } \\
\text { injection }\end{array}$ & Inhibiting the expression of bFGF \\
\hline $\begin{array}{l}\text { Curcumin (Wang et al., } \\
\text { 2015) }\end{array}$ & $\begin{array}{l}\text { 1) Human dermal microvascular } \\
\text { lymphatic endothelial cells } \\
\text { 2) C57BL/6mice }\end{array}$ & $\begin{array}{l}3,10 \mu \mathrm{M} \\
9 \mu \mathrm{g} \\
\text { Immersion administration }\end{array}$ & $\begin{array}{l}\text { Inhibited expressions of VEGF receptors (VEGFR2 and VEGFR3), as } \\
\text { well as downstream signaling such as phosphorylation of ERK and } \\
\text { FAK. }\end{array}$ \\
\hline $\begin{array}{l}\text { Curcumin (Matsuo et al., } \\
\text { 2007) }\end{array}$ & TR-LE cells & $20 \mu \mathrm{M} / 9 \mathrm{~h}$ & $\begin{array}{l}\text { Inhibiting the phosphorylation of Akt and enzymatic activity of MMP- } \\
2\end{array}$ \\
\hline Curcumin (Da et al., 2019) & $\begin{array}{l}\text { The Gastric cancer AGS and } \\
\text { SGC-7901 cell lines }\end{array}$ & $\begin{array}{l}0,10,15,20 \mu \mathrm{g} / \mathrm{mL} \\
\text { Immersion administration }\end{array}$ & $\begin{array}{l}\text { Eliminated the mRNA and protein expression levels of HMGB1 and } \\
\text { VEGF-D. }\end{array}$ \\
\hline CPT (Luo et al., 2011) & $\begin{array}{l}\text { The murine lymphatic endothelial } \\
\text { cells }\end{array}$ & $\begin{array}{l}0-10 \mu \mathrm{M} \\
\text { Immersion administration }\end{array}$ & $\begin{array}{l}\text { Inhibiting LEC tube formation: } \\
\text { 1) Inhibiting VEGFR-3-mediated ERK1/2 phosphorylation, } \\
\text { 2) Inhibiting expression of the small GTPases. }\end{array}$ \\
\hline NCTD (Liu et al., 2012) & Human LECs & $\begin{array}{l}1.25-15.00 \mu \mathrm{g} / \mathrm{mL} \\
\text { Immersion administration }\end{array}$ & Blocking VEGF-C and VEGF-DNEGFR-3 in vitro simultaneously. \\
\hline NCTD (Yuan et al., 2015) & $\begin{array}{l}\text { Human dermal lymphatic } \\
\text { endothelial cells }\end{array}$ & $\begin{array}{l}0,7.5,15,30,60,90 \mathrm{nmol} / \mathrm{L} \\
\text { Immersion administration }\end{array}$ & Down regulating the expression of VEGF-C and VEGF-D \\
\hline NCTD (Li et al., 2015) & $\begin{array}{l}\text { 1) The in-situ colonic xenografts } \\
\text { in nude mice } \\
\text { 2) Human colonic } \\
\text { adenocarcinoma HT-29 cell line }\end{array}$ & $\begin{array}{l}\text { 1) } 28 \mathrm{mg} / \mathrm{kg} \text { Gavage } \\
\text { administration } \\
\text { 2) } 1.25-100 \mu \mathrm{g} / \mathrm{mL} \\
\text { Immersion administration }\end{array}$ & Down regulating VEGF-A, -C, -D/NEGFR-2, -3 signaling pathways \\
\hline EEHDW (Li et al., 2019) & Human LECs & $\begin{array}{l}0,0.125,0.25,0.5 \text { and } 1 \mathrm{mg} / \mathrm{mL} \\
\text { Immersion administration }\end{array}$ & Down regulation of VEGF-C \\
\hline $\begin{array}{l}\text { Licoricidin (Park et al., } \\
\text { 2016) }\end{array}$ & $\begin{array}{l}\text { 1) } 4 T 1 \text { mammary tumor tissues } \\
\text { in BALB/c mice } \\
\text { 2) MCF-10A normal mammary } \\
\text { epithelial cells }\end{array}$ & $\begin{array}{l}\text { 1) } 2 \text { or } 4 \mathrm{mg} / \mathrm{kg} \\
\text { 2) } 0-5 \mu \mathrm{g} / \mathrm{mL} \\
\text { Immersion administration }\end{array}$ & Reduced the expression of VEGF-C, VEGF-R3, and LYVE-1 \\
\hline $\begin{array}{l}\text { Shikonin (Prangsaengtong } \\
\text { et al., 2018) }\end{array}$ & Human LECs & $0.8 \mu \mathrm{M}$ Immersion administration & $\begin{array}{l}\text { 1) Interfering the NF- } \kappa B / H I F-1 \alpha \text { pathway } \\
\text { 2) Suppressing VEGF-C and VEGFR-3 mRNA expression. }\end{array}$ \\
\hline Wogonin (Kimura and & 1) LM8-bearing mice & 1) $25,50 \mathrm{mg} / \mathrm{kg}$, twice daily & 1) Reducing VEGF-C-induced VEGFR-3 phosphorylation 2)Inhibiting \\
\hline Sumiyoshi, 2013) & 2) THP-1 macrophages & $\begin{array}{l}\text { 2) } 10,50,100 \mu \mathrm{M} \\
\text { Oral//mmersion administration }\end{array}$ & the expression of COX-2 and the production IL-1 $1 \beta$ \\
\hline $\begin{array}{l}\text { Oxyresveratrol (Kimura } \\
\text { and Sumiyoshi, 2016) }\end{array}$ & $\begin{array}{l}\text { 1) QGY-7701 and SMMC- } 7721 \\
\text { cells, } \\
\text { 2) male mice(lymph node } \\
\text { metastasis model) }\end{array}$ & $\begin{array}{l}\text { 1) } 20,40,80 \mu \mathrm{M} \\
\text { Immersion administration } \\
\text { 2) } 20,40,60 \mathrm{mg} / \mathrm{kg} \\
\text { Intraperitoneally injected }\end{array}$ & $\begin{array}{l}\text { 1) Decreased micro-blood vessel density and micro-lymphatic vessel } \\
\text { density, } \\
\text { 2) Inhibiting the expressions of CD31, VEGFR3, and VEGF-C }\end{array}$ \\
\hline $\begin{array}{l}\text { Resveratrol (Liu et al., } \\
\text { 2018) }\end{array}$ & $\begin{array}{l}\text { 1) M2 macrophage/Human LECs } \\
\text { 2) LM8-bearing mice }\end{array}$ & $\begin{array}{l}\text { 1) } 1,5,10,25,50 \mu \mathrm{M} \\
\text { 2) } 10,25 \mathrm{mg} / \mathrm{kg} \text {, twice daily }\end{array}$ & $\begin{array}{l}\text { 1) Inhibited the migration, invasion of VEGF-C-induced Human LECs. } \\
\text { 2) Regulatied the activation and differentiation of M2 macrophage } \\
\text { 3) Reduced the area of LECs }\end{array}$ \\
\hline
\end{tabular}


TABLE 4 | Continued

\begin{tabular}{|c|c|c|c|}
\hline Drug & Model & $\begin{array}{l}\text { Dosage and route of } \\
\text { administration }\end{array}$ & Mechanism \\
\hline $\begin{array}{l}\text { Hyperforin (Rothley et al., } \\
\text { 2009) }\end{array}$ & $\begin{array}{l}\text { 1) Female Wistar rats with tumor } \\
\text { 2) Primary human LECs, } \\
\text { HUVECs }\end{array}$ & $\begin{array}{l}\text { 1) } 100 \mu \mathrm{L} \text { of } 2 \mathrm{mM} \text { daily } 2 \text { week } \\
\text { 2) } 5,30 \mu \mathrm{M} 10 \text { days }\end{array}$ & Suppressed the proliferation of LECs \\
\hline $\begin{array}{l}\text { Liposomal honokiol (Wen } \\
\text { et al., 2009) }\end{array}$ & $\begin{array}{l}\text { 1) Lymph node metastasis } \\
\text { models (C57BL/6) mice } \\
\text { 2) HUVECs and Human LECs }\end{array}$ & $\begin{array}{l}\text { 1) Intraperitoneally injection once } \\
\text { a day for } 28 \text { days } \\
\text { 2) Immersion administration }\end{array}$ & Inhibiting the VEGFR-3 pathway \\
\hline
\end{tabular}

VEGF-C and VEGFR-3 are two major regulatory molecules of lymphangiogenesis. $\beta$-Elemene could restrain lymphangiogenesis in a dose-dependent pattern by manipulating the VEGF-C and VEGFR-3, which could be regarded as a potential mechanisms for its role in the prevention of lymphatic metastasis (Yan et al., 2014).

By inducing tumor cell apoptosis and downregulating the expression level of VEGF and bFGF, gecko is shown first time to play an anti-tumor role in vivo and in vitro (Liu et al., 2008). Later, Zhang et al. demonstrated that Gecko lyophilized powder, an active ingredient from the gecko, can inhibit the growth of tumors and also the lymphatic vessels in tumor-bearing mice (Figure 2). Combined with previous studies, they speculated that the mechanism of Gecko lyophilized powder on lymphangiogenesis involved affecting the expression of VEGF-C (Zhang et al., 2011). However, a more specific mechanism needs further research. Afterwards, more recent studies by Ding et al. shown that GSPP, an extract of the gecko, acquires the antitumor properties by decreasing the expression of bFGF-inhibiting the growth of lymphatic vessels in vitro and in vivo, which may further suppress lymphatic metastasis (Ding et al., 2016).

Curcumin is a phenolic pigment extracted from turmeric rhizomes of the ginger family. Curcumin suppressed VEGF-C induced lymphangiogenesis in a Matrigel plug assay in mice, and VEGF-C induced tube formation in human dermal LECs, demonstrating its anti-lymphangiogenic action in vivo and in vitro. It also demonstrated that curcumin inhibits lymphangiogenesis by inhibiting proliferation, cell cycle progression, and migration of LECs (Wang et al., 2015). Another work further showed that curcumin inhibited the tube-forming process in lymphatic, which partly through suppressing the phosphorylation of Akt and enzymatic activity of MMP-2 (Matsuo et al., 2007). In addition, curcumin significantly inhibited the mRNA andprotein expression of HMGB1 and VEGF-D. It was suggested that curcumin may play an antilymphangiogenesis role by inhibiting HMGB1/VEGF-D signaling pathway (Da et al., 2019).

CPT, a natural compound isolated from Danshen (Salvia miltiorrhiza), is a potential antitumor drug. Examined an in vitro model (LECs from mouse) pretreated with CPT, Luo et al. suggested that CPT can inhibit the formation of LECs partially by reducing the expression of the small GTPases or partially by suppressing the phosphorylation of ERK1/2 mediated by VEGFR-3 (Luo et al., 2011).

Norcantharidin (NCTD), a demethylated form of cantharidin, is an effective component of cantharidin. In several cell lines and tumor xenograft models, NCTD has been reported to have effective anti- angiogenic and anti-tumor properties (Ho et al., 2001; Fan et al., 2007; Chen et al., 2009; Fan et al., 2010; Deng and Tang, 2011; Zhang et al., 2012). However, its role in tumor associated lymphangiogenesis and lymphatic metastasis is not clear. Liu et al. confirmed for the first time that NCTD can inhibit the proliferation, migration, invasion, and lymphangiogenesis of HLEC; can induce the apoptosis of HLEC in a dose- and time-dependent manner; and can down regulate the protein and/or mRNA expression levels of VEGF-C, VEGF-D, and VEGFR-3 in the lymphangiogenesis of HLEC (Liu et al., 2012). Then, Yuan et al. further demonstrated that NCTD attenuates lymphangiogenesis by down regulating the expression level of VEGF-C and VEGF-D (Yuan et al., 2015). Afterwards, the effect of NCTD on lymphangiogenesis was observed in vitro and in vivo. It was found that NCTD could directly or indirectly down regulate the expression of VEGF-A, VEGF-C, VEGF-D, VEGFR-2, and VEGFR-3 in the process of lymphangiogenesis in vitro and in vivo and inhibit lymphangiogenesis (Li et al., 2015).

EEHDW is an ethanol extract of HDW. HDW, the member of the Rubiaceae family of shrubs, tropical herbs, and trees, is a Chinese herb. Li et al. investigated the effects of EEHDW on human LECs model stimulated by VEGF-C. It was found that EEHDW inhibited lymphangiogenesis by down regulating VEGF-C (Li et al., 2019).

Licoricidin, an active compound in the Hexane/Ethanol Extract of Glycyrrhiza Uralensis. Park et al. found that the expression of VEGF-R2, VEGF-C, VEGF-R3, and LYVE-1 decreased in licoricidin treated tumor tissues of mice, indicating that licoricidin can inhibit lymphangiogenesis (Park et al., 2016).

Shikonin, a natural compound found in the root of Lithospermum erythrorhizon, possesses multiple pharmacological activities, such as anti-cancer, anti-inflammation, and antiangiogenesis properties in in vitro and in vivo studies (Lee and Magesh, 2008; Lu et al., 2011) (Figure 2). It was found that shikonin inhibits pathological lymphangiogenesis, such as tumor induced lymphangiogenesis, by down regulating the expression of VEGF-C and VEGFR-3 genes in lymphangioendothelial cells (Prangsaengtong et al., 2018).

Wogonin, one of the effective components of Scutellaria baicalensis Georgi (Labiatae), is a flavonoid. Studies have shown that wogonin has anti-tumor and anti metastasis effects, which may be related to the inhibition of VEGF-C-induced lymphangiogenesis by inhibiting the expression of COX-2 and the production of IL-1 $\beta$ in TAMs (Kimura and Sumiyoshi, 2013).

Resveratrol is isolated from Polygonum cuspidatum roots. Works on resveratrol demonstrated that resveratrol-treated 
condition medium of M2 macrophages can inhibit the migration, invasion of VEGF-C-induced HLEC, and lymphangiogenesis, and resveratrol can reduce the area of LECs in tumors in vivo, which suggest that the antitumor effect of resveratrol were partly due to anti-lymphangiogenesis through the regulation of M2 macrophage activation and differentiation (Kimura and Sumiyoshi, 2016).

Oxyresveratrol, trans-2, 4, 3', 5'-tetrahydroxystilbene, is a derivative of Resveratrol. There is a study demonstrated that Oxyresveratrol significantly anti-tumor effects resulted from suppressing lymphangiogenesis through reducing the expression level of VEGF-C and VEGFR (Liu et al., 2018). Resveratrol and Oxyresveratrol may be a potential therapeutic agent for cancer.

Hyperforin, one of the main active constituents of Hypericum perforatum L, is a acylphloroglucinol-type compound substituted with lipophilic isoprene chains. Aristoforin is new chemical derivatives of hyperforin with improved stability and solubility properties. Both hyperforin and aristoforin significantly suppressed the proliferation of LECs (Rothley et al., 2009).

Honokiol, isolated from the bark of Magnoliae, is a bioactive constituent. Liposomal honokiol exerted a significant inhibitory effect on lymphangiogenesis by downregulation of the level of VEGF-D in VEGF-D-LL/2 cancer cells and interacting neogenesis and formation of LECs directly through the VEGFR-3 pathway. The findings suggest that liposomal honokiol may be a potential agent against lymphangiogenesis and metastasis (Wen et al., 2009).

\section{TCM (Table 5)}

Using LECs from the thoracic duct of pig, Li et al. suggests that Shenmai injection induces the apoptosis of LECs and the inhibition of lymphangiogenesis. Further work is needed to learn more about the mechanism of Shenmai injection on the growth of lymphatic vessels (Li et al., 2011).

Compared with model group, group pretreatment with Astragalus injection, the expressions of MLVD and the positive rate of HIF- $1 \alpha$ were significantly reduced in differentiated thyroid cancer (Li et al., 2014).

The cinobufacini injection is a traditional antitumor drug whose mechanism is still unclear (Figure 2). The effect of cinobufacini injection on HLEC migration, is through downregulating the expression of HGF and VEGFR-3. Cinobufacini injection can inhibit the migration, proliferation, and tube-like structure formation (Gao et al., 2013).

\section{TCM FORMULA (TABLE 6)}

\section{Experimental Research of TCM Formula}

Chinese medicine formula plays a significant role in traditional clinical treatment due to its characteristics of targeted treatment. Quite a few studies have found that TCM formulas are also potential inhibitors of lymphangiogenesis.

ATU I is an effective formula for treating advanced cancer, extracted and concentrated from eight kinds of TCM, such as coastal Glehnia root, Asparagus, Scutellaria baicalensis, etc (Figure 2). An inhibitory effect of ATU I on the lymphangiogenesis and the metastasis in liver cancer mice has been verified. The mechanism is associated with the downregulation of VEGF-C and Flt-4 (Gao et al., 2009).

RKY is a TCM formula composed of several specific Chinese medicines for treating breast cancer (Figure 2). One study pretreated with RKY found that RKY might inhibit the lymph node metastasis of breast cancer mainly through decreasing the expressions of VEGF-C and VEGFR-3 and inhibit lymphangiogenesis (Li and Dang, 2011). Another study from the same team has shown that RKY inhibited lymphangiogenesis partly by interfering with the Ang-2/Tie2 signaling pathway-inhibiting the protein expression of Ang-2 (Sun and Li, 2013). This indicates that RKY can inhibit lymphangiogenesis by affecting different signaling pathways. Importantly, Treatment with TCM formula can greatly make use of the characteristics of its multiple drug components and the advantages of multi-target therapy.

JFK, an oral liquid of Chinese herbal, has been used to treat NSCLC in clinics (Figure 2). The current research suggests that JFK prevents the migration and differentiation of LECs via regulating the expression of VEGF-C/VEGFR-3 and the SDF-1/ CXCR4. Consequently, JFK can suppress NSCLC through antilymphangiogenesis and is a promising antilymphangiogenesis agent (He et al., 2016). Another in vivo experimental study shows that bone marrow-derived mesenchymal stem cells (BMMSCs) differentiate into LECs by metastasis to tumors and participate in lymphangiogenesis of lung cancer in mice. Significantly, JFK inhibits the growth of lung tumors via suppressing the transformation of BMMSCs and lymphangiogenesis (Zhou et al., 2017).

JG-DS, composed of Pinellia, Celestial Star, Poria, white mustard, Chen Pi, Full Scorpion, Chicken inside gold, and Licorice, is an own Chinese medicine granules for inhibiting the recurrence and metastasis of cancer. Feng et al. found that

TABLE 5 | TCM for inhibiting lymphangiogenesis (TCM).

\begin{tabular}{|c|c|c|c|c|c|}
\hline Drug & Model & $\begin{array}{l}\text { Dosage and Route of } \\
\text { administration }\end{array}$ & Mechanism & $\begin{array}{l}\text { The herbal composition } \\
\text { (including the scientific name) }\end{array}$ & Ref \\
\hline $\begin{array}{l}\text { Shenmai } \\
\text { injection }\end{array}$ & $\begin{array}{l}\text { LECs which are } \\
\text { ducted from healthy } \\
\text { pig }\end{array}$ & $\begin{array}{l}\text { 0, 40,80, } 120,160 \mu \mathrm{g} / \mathrm{mL} \\
\text { Immersion administration }\end{array}$ & $\begin{array}{l}\text { 1) Inhibiting the proliferation of LECs } \\
\text { 2) Inducting the apoptosis of LECs }\end{array}$ & $\begin{array}{l}\text { Composed of Panax ginseng C. A. } \\
\text { Mey, Ophiopogon japonicus (Linn. f.) } \\
\text { Ker-Gawl. }\end{array}$ & (Li et al., 2011) \\
\hline $\begin{array}{l}\text { Astragalus } \\
\text { injection }\end{array}$ & $\begin{array}{l}\text { BALB/c nude mice } \\
\left(\mathrm{NIH} / 33^{\text {HOOK-RET }} \text { cell) }\right.\end{array}$ & $\begin{array}{l}5 \mathrm{~mL} / \mathrm{kg} \\
\text { Intraperitoneal injection }\end{array}$ & $\begin{array}{l}\text { Reducing the expression of MLVD and } \\
\text { the positive of rate of HIF- } \alpha\end{array}$ & $\begin{array}{l}\text { Astragalus membranaceus (Fisch.) } \\
\text { Bunge. }\end{array}$ & (Li et al., 2014) \\
\hline $\begin{array}{l}\text { Cinobufacini } \\
\text { injection }\end{array}$ & Human LECs & $\begin{array}{l}0.105,0.21,0.42 \mu \mathrm{g} / \mathrm{mL} \\
\text { Immersion administration }\end{array}$ & $\begin{array}{l}\text { 1) Inhibiting the proliferation, migration } \\
\text { and tubular structure formation of HLEC } \\
\text { 2) Down regulating the protein } \\
\text { expression of VEGFR-3 and HGF }\end{array}$ & $\begin{array}{l}\text { 14,15b-Epoxy-3b,5a,16b-trihydroxy- } \\
\text { 5b,20(22)-bufadienolide 16-acetate }\end{array}$ & (Gao et al., 2013) \\
\hline
\end{tabular}


TABLE 6 | TCM for inhibiting lymphangiogenesis (TCM formula).

\begin{tabular}{|c|c|c|c|c|c|}
\hline Drug & Model & $\begin{array}{l}\text { Dosage and Route } \\
\text { of administration }\end{array}$ & Mechanism & $\begin{array}{l}\text { The herbal composition } \\
\text { (including the scientific name) }\end{array}$ & Ref \\
\hline ATU I & $\begin{array}{l}615 \text { mouse model } \\
\text { of Hca-F hepatoma }\end{array}$ & $\begin{array}{l}0.4 \mathrm{~mL}(80 \mathrm{~g} / \mathrm{kg}) \\
\text { Hypodermic injection }\end{array}$ & $\begin{array}{l}\text { Down regulating the } \\
\text { expression of VEGF-C } \\
\text { and Flt-4 }\end{array}$ & $\begin{array}{l}\text { Composed of Glehnia littoralis, Asparagus } \\
\text { cochinchinensis(Lour)Merr, Taxus chinensis (Pilger) } \\
\text { Rehd., et al. }\end{array}$ & (Gao et al., 2009) \\
\hline RKY & $\begin{array}{l}\text { Transplantation } \\
\text { tumor spontaneous } \\
\text { metastasis model }\end{array}$ & $\begin{array}{l}18,45,90 \mathrm{~g} /(\mathrm{kg} \cdot \mathrm{d}) \\
\text { Gavage administration }\end{array}$ & $\begin{array}{l}\text { Intervening the } \\
\text { expressions of VEGF-C } \\
\text { and VEGFR3 }\end{array}$ & $\begin{array}{l}\text { Composed of Citrus reticulata Blanco, Bupleurum } \\
\text { chinense, Curcuma zedoaria (Christm.) Rosc. }\end{array}$ & $\begin{array}{l}\text { (Li and Dang, } \\
\text { 2011; Sun and Li, } \\
\text { 2013) }\end{array}$ \\
\hline JFK & $\begin{array}{l}\text { Mice lung cancer } \\
\text { model }\end{array}$ & $\begin{array}{l}15,30,60 \mathrm{~g} / \mathrm{kg} \\
\text { Oral administration }\end{array}$ & $\begin{array}{l}\text { Lower the number of } \\
\text { LYVE-1 positive cells }\end{array}$ & $\begin{array}{l}\text { Composed of Astragalus membranaceus (Fisch.) } \\
\text { Bunge., Glehnia littoralis, Ophiopogon japonicus } \\
\text { (Linn. f.) Ker-Gawl., Fructus Ligustri Lucidi, Cornus } \\
\text { officinalis Sieb. et Zucc., Gynostemma pentaphyllum } \\
\text { (Thunb.) Makino, et al. }\end{array}$ & $\begin{array}{l}\text { (He et al., 2016; } \\
\text { Zhou et al., 2017) }\end{array}$ \\
\hline JG-DS & Human LECs & $\begin{array}{l}200 \mu \mathrm{L} \\
\text { Immersion administration }\end{array}$ & $\begin{array}{l}\text { Inhibiting the tube } \\
\text { formation and migration } \\
\text { of HLECs }\end{array}$ & $\begin{array}{l}\text { Composed of Pinellia ternate, Arisaema erubescens } \\
\text { Wall.) Schott., Wolfiporia cocos, Semen sinapis, } \\
\text { Orange peel, Glycyrrhizae. }\end{array}$ & (Feng et al., 2016) \\
\hline $\mathrm{PZH}$ & $\begin{array}{l}\text { Human CRC cell } \\
\text { lines /Human LECs }\end{array}$ & $\begin{array}{l}0,0.25,0.5,0.75 \mathrm{mg} / \mathrm{mL} \\
\text { Immersion administration }\end{array}$ & $\begin{array}{l}\text { Down regulating the } \\
\text { expression of VEGF-C }\end{array}$ & $\begin{array}{l}\text { Composed of Bos taurus domesticus Gmelin, } \\
\text { Moschus, Panaxnotoginseng (Burk.) F.H.Chen, Snake } \\
\text { bile. }\end{array}$ & (Lin et al., 2016) \\
\hline $\begin{array}{l}\text { ShuGan- } \\
\text { JianPi }\end{array}$ & $\begin{array}{l}50 \text { Breast cancer } \\
\text { patients }\end{array}$ & $\begin{array}{l}20 \mathrm{~mL} \times 3 / \mathrm{d} \\
\text { Oral administration }\end{array}$ & $\begin{array}{l}\text { Decreasing the protein } \\
\text { expression of Ang2 } \\
\text { Increase the protein } \\
\text { expression of nm-23 }\end{array}$ & $\begin{array}{l}\text { Composed of Bupleurum chinense, Citrus reticulata } \\
\text { Blanco, Astragalus membranaceus (Fisch.) Bunge., } \\
\text { Wolfiporia cocos, Coix lacryma-jobi L.var.mayuen } \\
\text { (Roman.) Stapf }\end{array}$ & (Jin and Li, 2012) \\
\hline $\begin{array}{l}\text { TaoHong- } \\
\text { SiWu }\end{array}$ & $\begin{array}{l}40 \text { Breast cancer } \\
\text { patients }\end{array}$ & $\begin{array}{l}200 \mathrm{~mL} \times 3 / \mathrm{d} \\
\text { Oral administration }\end{array}$ & $\begin{array}{l}\text { Decreasing the } \\
\text { expression of LVD and } \\
\text { VEGF-C }\end{array}$ & $\begin{array}{l}\text { Composed of Prunus persica (L.) Batsch, Carthamus } \\
\text { tinctorius L., Angelica sinensis, Ligusticum chuanxiong } \\
\text { hort, Rehmannia glutinosa Libosch, et al. }\end{array}$ & (Chu et al., 2013) \\
\hline
\end{tabular}

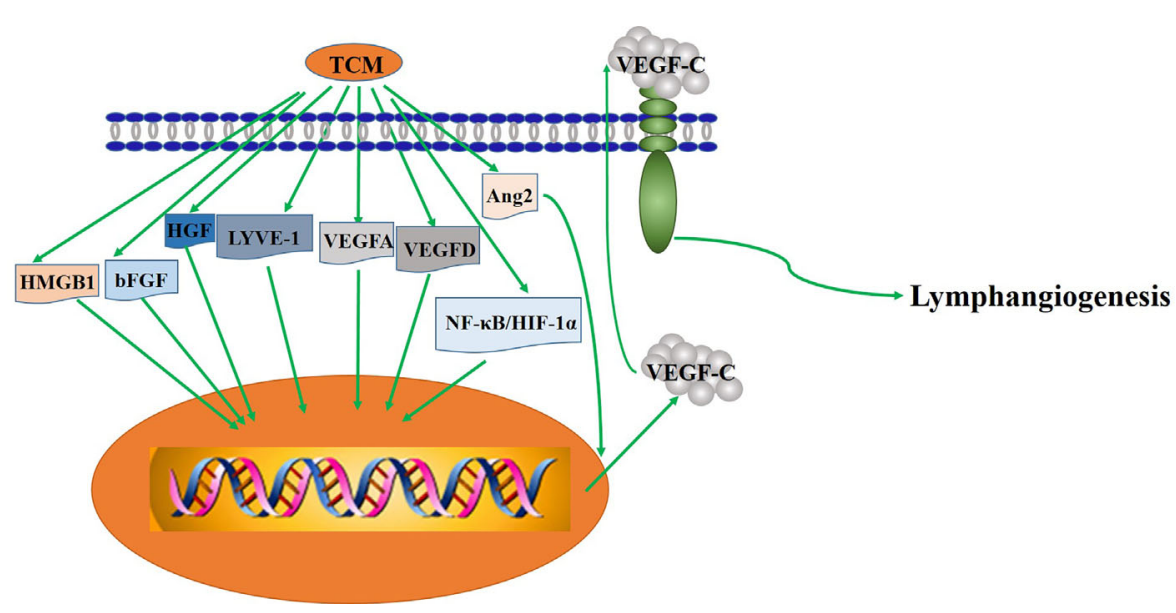

FIGURE 2 | The key mechanism of TCM regulating lymphangiogenesis.

JG-DS inhibited the tube formation and metastasis of human LECs in vitro, thereby directly inhibiting lymphangiogenesis (Feng et al., 2016).

$\mathrm{PZH}$, the main active ingredients include Moschus, Calculus Bovis, Snake Gall, and Radix Notoginseng, is a well-known traditional Chinese formula (Figure 2). Using different human colorectal cancer cell lines and human LECs model stimulated by VEGF-C, Lin et al. evaluated the effects of PZH on tumor metastasis and VEGF-C expression. It was found that $\mathrm{PZH}$ suppresses lymphangiogenesis via the downregulation of VEGF-C, which may be a potential molecular mechanism of inhibition of metastasis of colorectal cancer by PZH (Lin et al., 2016).

\section{Clinical Research of TCM Formula}

It is worth mentioning that related clinical studies show that two TCM formulas, Shu-GanJianPi formula and TaoHongSiWu formula, are inhibitors of lymphangiogenesis (Figure 2). In the first clinical study, all breast cancer patients (50 people) received CTF chemotherapy, and the test group (30 people) treated with Shugan Jianpi formula at the same time. After two courses of chemotherapy, 
all patients were operated on, and the MLVD and the expression of Ang-2 and nm23 in breast cancer tissues were detected by Bard biopsy needle biopsy, histology, and immunohistochemistry. The results show that ShuGanJianPi formula inhibits lymphatic metastasis in breast cancer by interfering with the expression of Ang-2 and nm23, which affects lymphangiogenesis (Jin and Li, 2012). Another clinical trial found that TaoHongSiWu Decoction can inhibit tumor lymphangiogenesis in breast cancer patients. Its mechanism of action is related to the inhibition of VEGF-C and LVD expression (Chu et al., 2013).

Taken together, there is good reason to believe that TCM regulating lymphangiogenesis may become a new tumor treatment method.

\section{CONCLUSION AND PERSPECTIVES}

In the past 20 years, clinical and experimental studies have revealed the basic role of lymphatics in the pathogenesis of many different diseases and revealed the potential role of lymphangiogenesis regulation in treatment and intervention. In fact, experimental studies have fully demonstrated the principle that although inhibition of lymphangiogenesis can limit tumor metastasis and potential graft rejection, stimulation of lymphangiogenesis can accelerate the regression of inflammation and edema. At present, most of the treatment studies focus on the VEGFC-VEGFDVEGFR3 pathway, including most of extracts from TCM the above mentioned, Injections of single TCM and formula.

In addition to VEGFC-VEGFD-VEGFR3 pathway, some of these TCM may work through an different mechanism. For example, licoricidin, GSPP/Gecko, curcumin, Astragalus injection, cinobufacini injection, JFK can inhibit lymphangiogenesis by suppressing the expression of LYVE-1, bFGF, inhibiting HMGB1/ VEGF-D signaling pathway, reducing the positive rate of HIF-1 $\alpha$, attenuating the expression of HGF, and weakening the expression of the SDF-1/CXCR4, respectively.

Moreover, PNS, promoted lymphangiogenesis, may be an attractive and suitable drug for the treatment of secondary lymphedema or other diseases related to lymphadenectomy. The combination of TCM and lymphangiogenesis provides an additional effect in the study of the regulation of lymphangiogenesis and related diseases.

\section{REFERENCES}

Achen, M. G., Jeltsch, M., Kukk, E., Vitali, A., Wilks, A. F., Alitalo, K., et al. (1998). Vascular endothelial growth factor D (VEGF-D) is a ligand for the tyrosine kinases VEGF receptor 2 (Flk1) and VEGF receptor 3 (Flt4). Proc. Natl. Acad. Sci. U.S.A. 95 (2), 548-553. doi: 10.1073/pnas.95.2.548

Achen, M. G., McColl, B. K., and Stacker, S. A. (2005). Focus on lymphangiogenesis in tumor metastasis. Cancer Cell. 7 (2), 121-127. doi: 10.1016/j.ccr.2005.01.017

Alitalo, K., Tammela, T., and Petrova, T. V. (2005). Lymphangiogenesis in development and human disease. Nature 438 (7070), 946-953. doi: 10.1038/nature04480

Alitalo, K. (2011). The lymphatic vasculature in disease. Nat. Med. 17 (11), 13711380. doi: $10.1038 / \mathrm{nm} .2545$

Arinaitwe, E., Sandison, T. G., Wanzira, H., Kakuru, A., Homsy, J., Kalamya, J., et al. (2009). Artemether-lumefantrine versus dihydroartemisinin-piperaquine
The regulatory effect of TCM on the lymphatic system has been confirmed in a variety of in vivo and in vitro models and some clinical experiments. In the past few years, advances in molecular extraction and synthesis technology of TCM, imaging technology, and animal models have helped us witness the important role of TCM in regulating lymphangiogenesis in many diseases, including cardiovascular disease, inflammation, and wound healing, especially cancer. Lymphangiogenesis is the main cause of the development and change of many diseases, and it even directly affects the pathological progress of disease. Currently, there are no agents specifically interfere with lymphangiogenesis, so it is urgent to develop effective agents to interfere with lymphangiogenesis. Now, the research on lymphangiogenesis regulators and the targets of TCM for regulating lymphangiogenesis has captured more attention. These research advances will provide new insights into the role of TCM in regulating lymphangiogenesis. Importantly, antilymphangiogenesis might become a new disease treatment method.

\section{AUTHOR CONTRIBUTIONS}

LP, YhW, and CZha conceived and designed the study. LP and YhW performed the experiments. LP and YhW wrote and revised the paper. YD, HF, MC, QW, YW, CZho, SL, and CZha reviewed and edited the manuscript. All authors contributed to the article and approved the submitted version.

\section{FUNDING}

This research was funded by National Natural Science Foundation of China (no. 81873264), Technological Innovation Action Plan of the Science and Technology Commission of Shanghai Municipality (no.15401902500 and no.17401901600) and Longhua Medical Scholar Project (no. LYTD-86).

\section{ACKNOWLEDGMENTS}

We thank Professor GuoSu for efforts to improve the language quality of the paper and ZhaoXiang for creative suggestions. They both came from the Department of Bioengineering and Therapeutic Sciences, University of California, San Francisco, CA, USA.

for falciparum malaria: a longitudinal, randomized trial in young Ugandan children. Clin. Infect. Dis. 49 (11), 1629-1637. doi: 10.1086/647946

Aspelund, A., Robciuc, M. R., Karaman, S., Makinen, T., and Alitalo, K. (2016). Lymphatic System in Cardiovascular Medicine. Circ. Res. 118 (3), 515-530. doi: 10.1161/CIRCRESAHA.115.306544

Avraham, T., Daluvoy, S., Zampell, J., Yan, A., Haviv, Y. S., Rockson, S. G., et al. (2010). Blockade of transforming growth factor-betal accelerates lymphatic regeneration during wound repair. Am. J. Pathol. 177 (6), 3202-3214. doi: 10.2353/ ajpath.2010.100594

Baluk, P., Tammela, T., Ator, E., Lyubynska, N., Achen, M. G., Hicklin, D. J., et al. (2005). Pathogenesis of persistent lymphatic vessel hyperplasia in chronic airway inflammation. J. Clin. Invest. 115 (2), 247-257. doi: 10.1172/JCI22037

Baluk, P., Hogmalm, A., Bry, M., Alitalo, K., Bry, K., and McDonald, D. M. (2013). Transgenic overexpression of interleukin- $1 \beta$ induces persistent lymphangiogenesis 
but not angiogenesis in mouse airways. Am. J. Pathol. 182 (4), 1434-1447. doi: 10.1016/j.ajpath.2012.12.003

Björndahl, M., Cao, R., Nissen, L. J., Clasper, S., Johnson, L. A., Xue, Y., et al. (2005). Insulin-like growth factors 1 and 2 induce lymphangio-genesis in vivo. Proc. Natl. Acad. Sci. U.S.A. 102 (43), 15593-15598. doi: 10.1073/pnas.0507865102

Bradham, R. R., and Parker, E. F. (1973). The cardiac lymphatics. Ann. Thorac. Surg. 15, 526-535. doi: 10.1016/s0003-4975(10)65339-8

Brakenhielm, E., and Alitalo, K. (2019). Cardiac lymphatics in health and disease. Nat. Rev. Cardiol. 16, 56-68. doi: 10.1038/s41569-018-0087-8

Brideau, G., Mäkinen, M. J., Elamaa, H., Tu, H., Nilsson, G., Alitalo, K., et al. (2007). Endostatin overexpression inhibits lymphangiogenesis and lymph node metastasis in mice. Cancer Res. 67 (24), 11528-11535. doi: 10.1158/0008-5472.CAN-07-1458

Cao, R., Björndahl, M. A., Religa, P., Clasper, S., Garvin, S., Galter, D., et al. (2004). PDGF-BB induces intratumoral lymphangia-aogenesis and promotes lymphatic metastasis. Cancer Cell. 6 (4), 333-345. doi: 10.1016/j.ccr.2004.08.034

Cao, R., Björndahl, M. A., Gallego, M. I., Chen, S., Religa, P., Hansen, A. J., et al. (2006). Hepatocyte growth factor is a lymphangiogenic factor with an indirect mechanism of action. Blood 107 (9), 3531-3536. doi: 10.1182/blood-2005-062538

Cao, R., Ji, H., Feng, N., Zhang, Y., Yang, X., Andersson, P., et al. (2012). Collaborative interplay between FGF-2 and VEGF-C promotes lymphangiogenesis and metastasis. Proc. Natl. Acad. Sci. U.S.A. 109 (39), 15894-15899. doi: 10.1073/pnas.1208324109

Chang, L. K., Garcia-Cardeña, G., Farnebo, F., Fannon, M., Chen, E. J., Butterfield, C., et al. (2004). Dose-dependent response of FGF-2 for lymphangiogenesis. PNAS 101 (32), 11658-11663. doi: 10.1073/pnas.0404272101

Chen, Y. J., Tsai, Y. M., Kuo, C. D., Ku, K. L., Shie, H. S., and Liao, H. F. (2009). Norcantharidin is a small-molecule synthetic compound with antiangiogenesis effect. Life Sci. 85 (17-18), 642-651. doi: 10.1016/j.lfs.2009.09.003

Chen, Y., Li, J., Li, Q., Wang, T., Xing, L., Xu, H., et al. (2016). Du-Huo-Ji-ShengTang Attenuates Inflammation of TNF-Tg Mice Related to Promoting Lymphatic Drainage Function. Evid. Based Complement Alternat. Med.2016, 7067691. doi: 10.1155/2016/7067691

Chu, A. J., Yang, H. Y., Tong, C. L., and Xie, D. (2013). Effects of Taohong Siwu Decoction on Lymphangiogenesis in Breast Cancer. Acta Chin. Med. Pharmacol. 41 (2), 38-40. doi: 10.3969/j.issn.1002-2392.2013.02.014

Clavin, N. W., Avraham, T., Fernandez, J., Daluvoy, S. V., Soares, M. A., Chaudhry, A., et al. (2008). TGF-betal is a negative regulator of lymphatic regeneration during wound repair. Am. J. Physiol. Heart Circ. Physiol. 295 (5), H2113-H2127. doi: 10.1152/ajpheart.00879.2008

Cuff, C. A., Schwartz, J., Bergman, C. M., Russell, K. S., Bender, J. R., and Ruddle, N. H. (1998). Lymphotoxin alpha3 induces chemokines and adhesion molecules: insight into the role of LT alpha in inflammation and lymphoid organ development. J. Immunol. 161 (12), 6853-6860.

Cui, Y. (2010). The role of lymphatic vessels in the heart. Pathophysiology 17 (4), 307-314. doi: 10.1016/j.pathophys.2009.07.006

Cursiefen, C., Maruyama, K., Bock, F., Saban, D., Sadrai, Z., Lawler, J., et al. (2011). Thrombospondin 1 inhibits inflammatory lymphangio-genesis by CD36 ligation on monocytes. J. Exp. Med. 208 (5), 1083-1092. doi: 10.1084/jem.20092277

Da, W., Zhang, J., Zhang, R., and Zhu, J. (2019). Curcumin inhibits the lymphangiogenesis of gastric cancer cells by inhibiton of HMGB1/VEGF-D signaling. Int. J. Immunopathol. Pharmacol. 33:2058738419861600. doi: 10.1177/2058738419861600

Dadras, S. S., Paul, T., Bertoncini, J., Brown, L. F., Muzikansky, A., Jackson, D. G., et al. (2003). Tumor lymphangiogenesis: a novel prognostic indicator for cutaneous melanoma metastasis and survival. Am. J. Pathol. 162 (6), 19511960. doi: 10.1016/S0002-9440(10)64328-3

Dadras, S. S., Lange-Asschenfeldt, B., Velasco, P., Nguyen, L., Vora, A., Muzikansky, A., et al. (2005). Tumor lymphangiogenesis predicts melanoma metastasis to sentinel lymph nodes. Mod. Pathol. 18 (9), 1232-1242. doi: 10.1038/modpathol.3800410

Dai, X. J., Lu, J. W., Wang, Z., Wu, Y. J., Ding, J., and Zhang, X. (2014). Effect of Ginsenoside Rg3 immune-nanoemulsion on growth and lymphangiogenesis of human gastric cancer cell transplantation tumor in nude mice. Chin. J. Cancer Prev. Treat. 21 (24), 1935-1939. doi: CNKI:SUN:QLZL.0.2014-24-003.

Dai, X., Liu, D., Liu, M., Zhang, X., Wang, W., Jin, F., et al. (2017). Anti-metastatic Efficacy of Traditional Chinese Medicine (TCM) Ginsenoside Conjugated to a VEFGR-3 Antibody on Human Gastric Cancer in an Orthotopic Mouse Model. Anticancer Res. 37 (3), 979-986. doi: 10.21873/anticanres.11407
Dashkevich, A., Hagl, C., Beyersdorf, F., Nykänen, A. I., and Lemström, K. B. (2016). VEGF pathways in the lymphatics of healthy and diseased heart. Microcirculation 23 (1), 5-14. doi: 10.1111/micc.12220

Deng, L., and Tang, S. (2011). Norcantharidin analogues: a patent review (2006-2010). Expert Opin. Ther. Pat. 21 (11), 1743-1753. doi: 10.1517/13543776.2011.629190

Ding, X. L., Man, Y. N., Hao, J., Zhu, C. H., Liu, C., Yang, X., et al. (2016). The Antitumor Effect of Gekko Sulfated Glycopeptide by Inhibiting bFGF-Induced Lymphangiogenesis. BioMed. Res. Int. 2016:7396392. doi: 10.1155/2016/ 7396392

D’Amico, G., Korhonen, E. A., Anisimov, A., Zarkada, G., Holopainen, T., Hägerling, R., et al. (2014). Tiel deletion inhibits tumor growth and improves angiopoietin antagonist therapy. J. Clin. Invest. 124 (2), 824-834. doi: 10.1172/JCI68897

Dunworth, W. P., Cardona-Costa, J., Bozkulak, E. C., Kim, J. D., Meadows, S., Fischer, J. C., et al. (2014). Bone morphogenetic protein 2 signaling negatively modulates lymphatic development in vertebrate embryos. Circ. Res. 114 (1), 56-66. doi: 10.1161/CIRCRESAHA.114.302452

Eriksson, A., Cao, R., Roy, J., Tritsaris, K., Wahlestedt, C., Dissing, S., et al. (2003). Small GTP-binding protein Rac is an essential mediator of vascular endothelial growth factor-induced endothelial fenestrations and vascular permeability. Circulation 107 (11), 1532-1538. doi: 10.1161/01.cir.0000055324.34758.32

Fan, Y. Z., Fu, J. Y., Zhao, Z. M., and Chen, C. Q. (2007). Inhibitory effect of norcantharidin on the growth of human gallbladder carcinoma GBC-SD cells in vitro. Hepatobiliary Pancreat. Dis. Int. 6 (1), 72-80.

Fan, Y. Z., Zhao, Z. M., Fu, J. Y., Chen, C. Q., and Sun, W. (2010). Norcantharidin inhibits growth of human gallbladder carcinoma xenografted tumors in nude mice by inducing apoptosis and blocking the cell cycle in vivo. Hepatobiliary Pancreat. Dis. Int. 9 (4), 414-422.

Feng, S. H., Gu, Y. F., Xu, J. Y., Zhang, Y. C., Zhao, Y., Lu, Y., et al. (2016). Effect of Jinlongshe Granule Drug-containing Serum on Tube Formation, Migration and Apoptosis of Human Lymphatic Endothelial Cellsin vitro. Chin. J. Integr. Tradit. West. Med. 36 (10), 1235-1240.

Furtado, G. C., Marinkovic, T., Martin, A. P., Garin, A., Hoch, B., Hubner, W., et al. (2007). Lymphotoxin beta receptor signaling is required for inflammatory lymphangiogenesis in the thyroid. Proc. Natl. Acad. Sci. U.S.A. 104 (12), 50265031. doi: 10.1073/pnas.0606697104

Gao, W. C., Yang, P., Xie, C. S., Wu, L. C., Feng, Y., Miao, Y. C., et al. (2009). The experiment research of inhibitory effect of ATU-I on lymphangiogenesis of HC a-F liver cancer in 615 mice. J. Mod. Oncol. 17 (12), 2256-2259. doi: 10.3969/ j.issn.1672-4992.2009.12.004

Gao, S., Chen, X. Y., Fu, H. Y., and Cui, X. N. (2013). The effect of cinobufacini injection on proliferation and tube-like structure formation of human lymphatic endothelial cells. China Oncol. 23 (01), 36-41. doi: 10.3969/j.issn.1007-3969.2013.01.006

Guidolin, D., Albertin, G., Spinazzi, R., Sorato, E., Mascarin, A., Cavallo, D., et al. (2008). Adrenomedullin stimulates angiogenic response in cultured human vascular endothelial cells: involvement of the vascular endothelial growth factor receptor 2. Peptides 29 (11), 2013-2023. doi: 10.1016/j.peptides.2008.07.009

Guo, X. Y., Liu, J., Li, H. J., Qi, Y., Qin, L. P., Wang, M., et al. (2013). Use of traditional Chinese medicine in Chinese patients with coronary heart disease. BioMed. Environ. Sci. 26 (4), 303-310. doi: 10.3967/0895-3988.2013.04.009

Han, L., Zhang, M., Liang, X., Jia, X., Jia, J., Zhao, M., et al. (2017). Interleukin-33 promotes inflammation-induced lymphangiogenesis via ST2/TRAF6-mediated Akt/eNOS/NO signalling pathway. Sci. Rep. 7 (1), 10602. doi: 10.1038/s41598017-10894-x

He, Y., Kozaki, K., Karpanen, T., Koshikawa, K., Yla-Herttuala, S., Takahashi, T., et al. (2002). Suppression of tumor lymphangiogenesis and lymph node metastasis by blocking vascular endothelial growth factor receptor 3 signaling. J. Natl. Cancer Inst. 94 (11), 819-825. doi: 10.1093/jnci

He, Y., Rajantie, I., Pajusola, K., Jeltsch, M., Holopainen, T., Yla-Herttuala, S., et al. (2005). Vascular endothelial cell growth factor receptor 3-mediated activation of lymphatic endothelium is crucial for tumor cell entry and spread via lymphatic vessels. Cancer Res. 65 (11), 4739-4746. doi: 10.1158/0008-5472

He, H. L., Wang, D., Tang, J., Zhou, X. M., Li, J. X., and Xu, L. (2016). Jin Fu Kang Oral Liquid Inhibits Lymphatic Endothelial Cells Formation and Migration. Evid. Based Complement Alternat. Med. 2016, 3635209. doi: 10.1155/2016/3635209

Henri, O., Pouehe, C., Houssari, M., Galas, L., Nicol, L., Edwards-Lévy, F., et al. (2016). Selective stimulation of cardiac lymphangiogenesis reduces myocardial edema and 
fibrosis leading to improved cardiac function following myocardial infarction. Circulation 133 (15), 1484-1497. doi: 10.1161/CIRCULATIONAHA.115.020143

Hjelmström, P., Fjell, J., Nakagawa, T., Sacca, R., Cuff, C. A., and Ruddle, N. H. (2000). Lymphoid tissue homing chemokines are expressed in chronic inflammation. Am. J. Pathol. 156 (4), 1133-1138. doi: 10.1016/S0002-9440 (10)64981-4

Ho, Y. P., To, K. K., Au-Yeung, S. C., Wang, X., Lin, G., and Han, X. (2001). Potential new antitumor agents from an innovative combination of demethylcantharidin, a modified traditional Chinese medicine, with a platinum moiety. J. Med. Chem. 44 (13), 2065-2068. doi: 10.1021/jm000476t

Hong, H., Jiang, L., Lin, Y., He, C., Zhu, G., Du, Q., et al. (2016). TNF-alpha promotes lymphangiogenesis and lymphatic metastasis of gallbladder cancer through the ERK1/2/AP-1/VEGF-D pathway. BMC Cancer 16, 240. doi: 10.1186/s12885-0162259-4

Irigoyen, M., Ansó, E., Martínez, E., Garayoa, M., Martínez-Irujo, J. J., and Rouzaut, A. (2007). Hypoxia alters the adhesive properties of lymphatic endothelial cells. A transcriptional and functional study. Biochim. Biophys. Acta 1773 (6), 880-890. doi: 10.1016/j.bbamcr.2007.03.001

Ishikawa, Y., Akishima-Fukasawa, Y., Ito, K., Akasaka, Y., Tanaka, M., Shimokawa, R., et al. (2007). Lymphangiogenesis in myocardial remodelling after infarction. Histopathology 51 (3), 345-353. doi: 10.1111/j.1365-2559.2007.02785.x

Jeltsch, M., Kaipainen, A., Joukov, V., Lakso, M., Rauvala, H., Swartz, M., et al. (1997). Hyperplasia of lymphatic vessels in VEGF-C transgenic mice. Science 276 (5317), 1423-1425. doi: 10.1126/science.276.5317.1423

Jha, S. K., Rauniyar, K., Karpanen, T., Leppänen, V. M., Brouillard, P., Vikkula, M., et al. (2017). Efficient activation of the lymphangiogenic growth factor VEGF$\mathrm{C}$ requires the C-terminal domain of VEGF-C and the N-terminal domain of CCBE1. Sci. Rep. 7 (1), 4916. doi: 10.1038/s41598-017-04982-1

Jiang, W., Hiscox, S., Matsumoto, K., and Nakamura, T. (1999). Hepatocyte growth factor/scatter factor, its molecular, cellular and clinical implications in cancer. Crit. Rev. Oncol. Hematol. 29 (3), 209-248. doi: 10.1016/s1040-8428 (98)00019-5

Jin, P. Y., and Li, X. Q. (2012). Effects of Shugan jianpi formula on lymphangiogenesis and expressions of Ang-2 and $\mathrm{nm} 23$ in breast cancer tissue. J. TaiShan Med. Coll. 33 (6), 420-423.

Joukov, V., Pajusola, K., Kaipainen, A., Chilov, D., Lahtinen, I., Kukk, E., et al. (1996). A novel vascular endothelial growth factor, VEGF-C, is a ligand for the Flt4 (VEGFR-3) and KDR (VEGFR-2) receptor tyrosine kinases. EMBO J. 15 (2), 290-298. doi: 10.1002/j.1460-2075.1996.tb00359.x

Joukov, V., Sorsa, T., Kumar, V., Jeltsch, M., Claesson-Welsh, L., Cao, Y., et al. (1997). Proteolytic processing regulates receptor specificity and activity of VEGF-C. EMBO J. 16 (13), 3898-3911. doi: 10.1093/emboj/16.13.3898

Kajiya, K., and Detmar, M. (2006). An important role of lymphatic vessels in the control of UVB-induced edema formation and inflammation. J. Invest. Dermatol. 126 (4), 919-921. doi: 10.1038/sj.jid.5700126

Karpanen, T., Egeblad, M., Karkkainen, M. J., Kubo, H., Ylä-Herttuala, S., Jä̈ttelä, M., et al. (2001). Vascular endothelial growth factor C promotes tumor lymphangiogenesis and intralymphatic tumor growth. Cancer Res. 61 (5), 1786-1790.

Kataru, R. P., Kim, H., Jang, C., Choi, D. K., Koh, B. I., Kim, M., et al. (2011). T lymphocytes negatively regulate lymph node lymphatic vessel formation. Immunity 34 (1), 96-107. doi: 10.1016/j.immuni.2010.12.016

Katsuta, M., Miyashita, M., Makino, H., Nomura, T., Shinji, S., Yamashita, K., et al. (2005). Correlation of hypoxia inducible factor-1alpha with lymphatic metastasis via vascular endothelial growth factor-C in human esophageal cancer. Exp. Mol. Pathol. 78 (2), 123-130. doi: 10.1016/j.yexmp.2004.11.002

Kazenwadel, J., Secker, G. A., Betterman, K. L., and Harvey, N. L. (2012). In vitro assays using primary embryonic mouse lymphatic endothelial cells uncover key roles for FGFR1 signaling in lymphangiogenesis. PloS One 7 (7), e40497. doi: 10.1371/journal.pone.0040497

Kholová, I., Dragneva, G., Cermáková, P., Laidinen, S., Kaskenpää, N., Hazes, T., et al. (2011). Lymphatic vasculature is increased in heart valves, ischaemic and inflamed hearts and in cholesterol-rich and calcified atherosclerotic lesions. Eur. J. Clin. Invest. 41 (5), 487-497. doi: 10.1111/j.1365-2362.2010.02431.x

Kim, K. E., Cho, C. H., Kim, H. Z., Baluk, P., McDonald, D. M., and Koh, G. Y. (2007). In vivo actions of angiopoietins on quiescent and remodeling blood and lymphatic vessels in mouse airways and skin. Arterioscler. Thromb. Vasc. Biol. 27 (3), 564-570. doi: 10.1161/01.ATV.0000256458.82320.be
Kimura, Y., and Sumiyoshi, M. (2013). Anti-tumor and anti-metastatic actions of wogonin isolated from Scutellaria baicalensis roots through antilymphangiogenesis. Phytomedicine 20 (3-4), 328-336. doi: 10.1016/j.phymed. 2012.10.016

Kimura, Y., and Sumiyoshi, M. (2016). Resveratrol Prevents Tumor Growth and Metastasis by Inhibiting Lymphangiogenesis and M2 Macrophage Activation and Differentiation in Tumor-associated Macrophages. Nutr. Cancer 68 (4), 667-678. doi: 10.1080/01635581.2016.1158295

Klotz, L., Norman, S., Vieira, J. M., Masters, M., Rohling, M., Dubé, K. N., et al. (2015). Cardiac lymphatics are heterogeneous in origin and respond to injury. Nature 522 (7554), 62-67. doi: 10.1038/nature14483

Kubo, H., Cao, R., Brakenhielm, E., Mäkinen, T., Cao, Y., and Alitalo, K. (2002). Blockade of vascular endothelial growth factor receptor-3 signaling inhibits fibroblast growth factor-2-induced lymphangiogenesis in mouse cornea. Proc. Natl. Acad. Sci. U.S.A. 99 (13), 8868-8873. doi: 10.1073/pnas.062040199

Kunstfeld, R., Hirakawa, S., Hong, Y. K., Schacht, V., Lange-Asschenfeldt, B., Velasco, P., et al. (2004). Induction of cutaneous delayed-type hypersensitivity reactions in VEGF-A transgenic mice results in chronic skin inflammation associated with persistent lymphatic hyperplasia. Blood 104 (4), 1048-1057. doi: 10.1182/blood-2003-08-2964

Larrieu-Lahargue, F., Welm, A. L., Thomas, K. R., and Li, D. Y. (2010). Netrin-4 induces lymphangiogenesis in vivo. Blood 115 (26), 5418-5426. doi: 10.1182/ blood-2009-11-252338

Lee, H. J., and Magesh, V. (2008). Shikonin, acetylshikonin, and isobutyroylshikonin inhibit VEGF-induced angiogenesis and suppress tumor growth in lewis lung carcinoma-bearing mice. Yakugaku Zasshi 128 (11), 1681-1688. doi: 10.1248/yakushi.128.1681

Lee, S., Rho, S. S., Park, H., Park, J. A., Kim, J., Lee, I. K., et al. (2017). Carbohydrate-binding protein CLEC14A regulates VEGFR-2- and VEGFR3 -dependent signals during angiogenesis and lymphangiogenesis. J. Clin. Invest. 127 (2), 457-471. doi: 10.1172/JCI85145

Lenoir, B., Wagner, D. R., Blacher, S., Sala-Newby, G. B., Newby, A. C., Noel, A., et al. (2014). Effects of adenosine on lymphangiogenesis. PloS One 9 (3), e92715. doi: 10.1371/journal.pone.0092715

Li, X. Q., and Dang, X. G. (2011). Intervention of Rukangyin on the Lymphangiogenesis in Breast Cancer Spontaneous Metastasis Nude Mouse Model. Chin. J. Integr. Tradit. West. Med. 31, 1657-1661. doi: 10.7661/CJIM.2011.12.1657

Li, J. W., and Vederas, J. C. (2009). Drug discovery and natural products: end of an era or an endless frontier? Science 325 (5937), 161-165. doi: 10.1126/science.1168243

Li, M. Q., Teng, C. Y., Yang, C. Z., Zhang, D. W., Liu, Y. G., and Feng, K. J. (2009). Influence of 20 (R)-ginsenoside Rg3 on lymphangenesis. Anat. Res. 31, 81-84. (In Chinese, CNKI:SUN:GDJP.0.2009-02-003).

Li, M. Q., Yang, C. Z., and Wang, Y. (2011). Effects of Shenmai Injection on Proliferation and Apoptosis of Lymphatic Endothelial Cells. J. Anhui Tradit. Chin. Med. Coll. 30, 48-50. doi: 10.3969/j.issn.1000-2219.2011.03.019

Li, Z. J., Ying, X. J., Chen, H. L., Ye, P. J., Chen, Z. L., Li, G., et al. (2013). Insulinlike growth factor-1 induces lymphangiogenesis and facilitates lymphatic metastasis in colorectal cancer. World J. Gastroenterol. 19 (43), 7788-7794. doi: 10.3748/wjg.v19.i43.7788

Li, Y., Zhang, X. X., Liu, Y. J., Lv, B. J., and Zeng, Q. A. (2014). Effects of Astragalus Injection on Micro Lymphatic Vessel Density and HIF-1 $\alpha$ Expressions in Organization for Differentiated Thyroid Cancer. Chin. J. Tradit. Med. Sci. Technol. 21, 391-392+394.

Li, X. P., Jing, W., Sun, J. J., Liu, Z. Y., Zhang, J. T., Sun, W., et al. (2015). A potential small-molecule synthetic antilymphangiogenic agent norcantharidin inhibits tumor growth and lymphangiogenesis of human colonic adenocarcinomas through blocking VEGF-A,-C,-D/VEGFR-2,-3 "multipoints priming" mechanisms in vitro and in vivo. BMC Cancer 15, 527. doi: 10.1186/s12885-015-1521-5

Li, J., Chen, Y., Zhang, L., Xing, L., Xu, H., Wang, Y., et al. (2016). Total saponins of panaxnotoginseng promotes lymphangiogenesis by activation VEGF-C expression of lymphatic endothelial cells. J. Ethnopharmacol. 193, 293-302. doi: 10.1016/j.jep.2016.08.032

Li, H., Lai, Z., Yang, H., Peng, J., Chen, Y., and Lin, J. (2019). Hedyotis diffusa Willd. inhibits VEGF-C-mediated lymphangiogenesis in colorectal cancer via multiple signaling pathways. Oncol. Rep. 42 (3), 1225-1236. doi: 10.3892/ or.2019.7223 
Liang, Q., Ju, Y., Chen, Y., Chen, Y., Wang, W., Li, J., et al. (2016). Lymphatic endothelial cells efferent to inflamed joints produce iNOS and inhibit lymphatic vessel contraction and drainage in TNF-induced arthritis in mice. Arthritis Res. Ther. 18, 62. doi: 10.1186/s13075-016-0963-8

Lin, J., Lalani, A. S., Harding, T. C., Gonzalez, M., Wu, W. W., Luan, B., et al. (2005). Inhibition of lymphogenous metastasis using adeno-associated virusmediated gene transfer of a soluble VEGFR-3 decoy receptor. Cancer Res. 65 (15), 6901-6909. doi: 10.1158/0008-5472.CAN-05-0408

Lin, J., Feng, J., Jin, Y., Yan, Z., Lai, Z., and Peng, J. (2016). Pien Tze Huang suppresses VEGF-C -mediated lymphangiogenesis in colorectal cancer. Oncol. Rep. 36 (6), 3568-3576. doi: 10.3892/or.2016.5186

Lisewski, A. M., Quiros, J. P., Ng, C. L., Adikesavan, A. K., Miura, K., Putluri, N., et al. (2014). Supergenomic network compression and the discovery of EXP1 as a glutathione transferase inhibited by artesunate. Cell 158 (4), 916-928. doi: $10.1016 /$ j.cell.2014.07.011

Liu, F., Wang, J. G., Wang, S. Y., Li, Y., Wu, Y. P., and Xi, S. M. (2008). Antitumor effect and mechanism of Gecko on human esophageal carcinoma cell lines in vitro and xenografted sarcoma 180 in Kunming mice. World J. Gastroenterol. 14 (25), 3990-3996. doi: 10.3748/wjg.14.3990

Liu, Z. Y., Qiu, H. O., Yuan, X. J., Ni, Y. Y., Sun, J. J., Jing, W., et al. (2012). Suppression of lymphangiogenesis in human lymphatic endothelial cells by simultaneously blocking VEGF-C and VEGF-D/VEGFR-3 with norcantharidin. Int. J. Oncol. 41 (5), 1762-1772. doi: 10.3892/ijo.2012.1603

Liu, Y., Ren, W., Bai, Y., Wan, L., Sun, X., Liu, Y., et al. (2018). Oxyresveratrol prevents murine $\mathrm{H} 22$ hepatocellular carcinoma growth and lymph node metastasis via inhibiting tumor angiogenesis and lymphangiogenesis. J. Nat. Med. 72 (2), 481-492. doi: 10.1007/s11418-018-1173-2

Lu, L., Qin, A., Huang, H., Zhou, P., Zhang, C., Liu, N., et al. (2011). Shikonin extracted from medicinal Chinese herbs exerts anti-inflammatory effect via proteasome inhibition. Eur. J. Pharmacol. 658 (2-3), 242-247. doi: 10.1016/ j.ejphar.2011.02.043

Luo, Y., Chen, W., Zhou, H., Liu, L., Shen, T., Alexander, J. S., et al. (2011). Cryptotanshinone inhibits lymphatic endothelial cell tube formation by suppressing VEGFR-3/ERK and small GTPase pathways. Cancer Prev. Res. (Phila). 4 (12), 2083-2091. doi: 10.1158/1940-6207.CAPR-11-0319

Matsuo, M., Sakurai, H., Koizumi, K., and Saiki, I. (2007). Curcumin inhibits the formation of capillary-like tubes by rat lymphatic endothelial cells. Cancer Lett. 251 (2), 288-295. doi: 10.1016/j.canlet.2006.11.027

Mohamadzadeh, M., DeGrendele, H., Arizpe, H., Estess, P., and Siegelman, M. (1998). Proinflammatory stimuli regulate endothelial hyaluronan expression and CD44/HA-dependent primary adhesion. J. Clin. Invest. 101 (1), 97-108. doi: $10.1172 / \mathrm{JCI} 1604$

Morgillo, F., De Vita, F., Antoniol, G., Orditura, M., Auriemma, P. P., Diadema, M. R., et al. (2013). Serum insulin-like growth factor 1 correlates with the risk of nodal metastasis in endocrine-positive breast cancer. Curr. Oncol. 20 (4), e283-e288. doi: 10.3747/co.20.1380

Morisada, T., Oike, Y., Yamada, Y., Urano, T., Akao, M., Kubota, Y., et al. (2005). Angiopoietin-1 promotes LYVE-1-positive lymphatic vessel formation. Blood 105 (12), 4649-4656. doi: 10.1182/blood-2004-08-3382

Mounzer, R. H., Svendsen, O. S., Baluk, P., Bergman, C. M., Padera, T. P., Wiig, H., et al. (2010). Lymphotoxin-alpha contributes to lymphangiogenesis. Blood 116 (12), 2173-2182. doi: 10.1182/blood-2009-12-256065

Nicoli, S., Tobia, C., Gualandi, L., De Sena, G., and Presta, M. (2008). Calcitonin receptor-like receptor guides arterial differentiation in zebrafish. Blood 111 (10), 4965-4972. doi: 10.1182/blood-2007-10-118166

Normile, D. (2003). Asian medicine. The new face of traditional Chinese medicine. Science 299 (5604), 188-190. doi: 10.1126/science.299.5604.188

Oka, M., Iwata, C., Suzuki, H. I., Kiyono, K., Morishita, Y., Watabe, T., et al. (2008). Inhibition of endogenous TGF-beta signaling enhances lymphangiogenesis. Blood 111 (9), 4571-4579. doi: 10.1182/blood-2007-10-120337

Ota, H., Katsube, K., Ogawa, J., and Yanagishita, M. (2007). Hypoxia/Notch signaling in primary culture of rat lymphatic endothelial cells. FEBS Lett. 581 (27), 5220-5226. doi: 10.1016/j.febslet.2007.10.009

Park, S. Y., Kwon, S. J., Lim, S. S., Kim, J. K., Lee, K. W., Han, J., et al. (2016). Licoricidin, an Active Compound in the Hexane/Ethanol Extract of Glycyrrhiza uralensis, Inhibits Lung Metastasis of 4T1 Murine Mammary Carcinoma Cells. Int. J. Mol. Sci. 17 (6):934. doi: 10.3390/ijms17060934
Polzer, K., Baeten, D., Soleiman, A., Distler, J., Gerlag, D. M., Tak, P. P., et al. (2008). Tumour necrosis factor blockade increases lymphangiogenesis in murine and human arthritic joints. Ann. Rheum. Dis. 67 (11), 1610-1616. doi: 10.1136/ard.2007.083394

Prangsaengtong, O., Jantaree, P., Lirdprapamongkol, K., Svasti, J., and Koizumi, K. (2018). Shikonin Suppresses Lymphangiogenesis via NF-KB/HIF-1 $\alpha$ Axis Inhibition. Biol. Pharm. Bull. 41 (11), 1659-1666. doi: 10.1248/bpb.b18-00329

Randolph, G. J., Ivanov, S., Zinselmeyer, B. H., and Scallan, J. P. (2017). The lymphatic system: integral roles in immunity. Annu. Rev. Immunol. 35, 31-52. doi: 10.1146/annurev-immunol-041015-055354

Ristimäki, A., Narko, K., Enholm, B., Joukov, V., and Alitalo, K. (1998). Proinflammatory cytokines regulate expression of the lymphatic endothelial mitogen vascular endothelial growth factor-C. J. Biol. Chem. 273 (14), 84138418. doi: $10.1074 / j b c .273 .14 .8413$

Rothley, M., Schmid, A., Thiele, W., Schacht, V., Plaumann, D., Gartner, M., et al. (2009). Hyperforin and aristoforin inhibit lymphatic endothelial cell proliferation in vitro and suppress tumor-induced lymphangiogenesis in vivo. Int. J. Cancer 125 (1), 34-42. doi: 10.1002/ijc.24295

Sacca, R., Cuff, C. A., Lesslauer, W., and Ruddle, N. H. (1998). Differential activities of secreted lymphotoxin-alpha3 and membrane lymphotoxin-alphalbeta2 in lymphotoxin-induced inflammation: critical role of TNF receptor 1 signaling. J. Immunol. 160 (1), 485-491.

Saito, Y., Nakagami, H., Morishita, R., Takami, Y., Kikuchi, Y., Hayashi, H., et al. (2006). Transfection of human hepatocyte growth factor gene ameliorates secondary lymphedema via promotion of lymphangiogenesis. Circulation 114 (11), 1177-1184. doi: 10.1161/CIRCULATIONAHA.105.602953

Schoppmann, S. F., Fenzl, A., Schindl, M., Bachleitner-Hofmann, T., Nagy, K., Gnant, M., et al. (2006). Hypoxia inducible factor-lalpha correlates with VEGF-C expression and lymphangiogenesis in breast cancer. Breast Cancer Res. Treat. 99 (2), 135-141. doi: 10.1007/s10549-006-9190-3

Schoppmann, S. F., Alidzanovic, L., Schultheis, A., Perkmann, T., Brostjan, C., and Birner, P. (2013). Thrombocytes Correlate with Lymphangiogenesis in Human Esophageal Cancer and Mediate Growth of Lymphatic Endothelial Cells In Vitro. PloS One 8 (6), e66941. doi: 10.1371/journal.pone.0066941

Sleeman, J. P., and Thiele, W. (2009). Tumor metastasis and the lymphatic vasculature. Int. J. Cancer 125, 2747-2756. doi: 10.1002/ijc.24702

Spinella, F., Garrafa, E., Di Castro, V., Rosanò, L., Nicotra, M. R., Caruso, A., et al. (2009). Endothelin-1 stimulates lymphatic endothelial cells and lymphatic vessels to grow and invade. Cancer Res. 69 (6), 2669-2676. doi: 10.1158/00085472.CAN-08-1879

Stacker, S. A., Caesar, C., Baldwin, M. E., Thornton, G. E., Williams, R. A., Prevo, R., et al. (2001). VEGF-D promotes the metastatic spread of tumor cells via the lymphatics. Nat. Med. 7 (2), 186-191. doi: 10.1038/84635

Stacker, S. A., Williams, S. P., Karnezis, T., Shayan, R., Fox, S. B., and Achen, M. G. (2014). Lymphangiogenesis and lymphatic vessel remodelling in cancer. Nat. Rev. Cancer 14 (3), 159-172. doi: 10.1038/nrc3677

Sun, X. B., and Li, X. Q. (2013). Effect of Rukang Yin on inhibiting lymphatic metastasis of Ang-2 expression in breast cancer tissues of nude mice. J. Med. Res. 9, 70-74. doi: 10.3969/j.issn.1673-548X.2013.09.024

Tammela, T., Saaristo, A., Lohela, M., Morisada, T., Tornberg, J., Norrmén, C., et al. (2005). Angiopoietin-1 promotes lymphatic sprouting and hyperplasia. Blood 105 (12), 4642-4648. doi: 10.1182/blood-2004-08-3327

Tang, J. L., Liu, B. Y., and Ma, K. W. (2008). Traditional Chinese medicine. Lancet 372 (9654), 1938-1940. doi: 10.1016/S0140-6736(08)61354-9

Tobler, N. E., and Detmar, M. (2006). Tumor and lymph node lymphangiogenesisimpact on cancer metastasis. J. Leukoc. Biol. 80 (4), 691-696. doi: 10.1189/jb.1105653

Vaahtomeri, K., Karaman, S., Mäkinen, T., and Alitalo, K. (2017). Lymphangiogenesis guidance by paracrine and pericellular factors. Genes Dev. 31 (16), 1615-1634. doi: $10.1101 /$ gad.303776.117

Veikkola, T., Jussila, L., Makinen, T., Karpanen, T., Jeltsch, M., Petrova, T. V., et al. (2001). Signalling via vascular endothelial growth factor receptor-3 is sufficient for lymphangiogenesis in transgenic mice. EMBO J. 20 (6), 1223-1231. doi: $10.1093 / \mathrm{emboj} / 20.6 .1223$

Wang, J., Guo, Y., Zhang, B. C., Chen, Z. T., and Gao, J. F. (2007). Induction of apoptosis and inhibition of cell migration and tube-like formation by dihydroartemisinin in murine lymphatic endothelial cells. Pharmacology 80, 207-218. doi: 10.1159/ 000104418 
Wang, J., Zhang, B., Guo, Y., Li, G., Xie, Q., Zhu, B., et al. (2008). Artemisinin inhibits tumor lymphangiogenesis by suppression of vascular endothelial growth factor C. Pharmacology 82 (2), 148-155. doi: 10.1159/000148261

Wang, Q., Wu, M. Q., Zhao, L. H., Yang, H. K., and Lv, X. H. (2008). Effect of ginsenoside $\mathrm{Rh} 2$ on transplanted-tumor and expression of JAM in mice. Zhongguo Zhong Yao Za Zhi 33 (18), 2116-2119. ( In Chinese, PMID: 19160799).

Wang, J., Zhang, C. J., Chia, W. N., Loh, C. C. Y., Li, Z., Lee, Y. M., et al. (2015). Haem-activated promiscuous targeting of artemisinin in Plasmodium falciparum. Nat. Commun. 6:10111. doi: 10.1038/ncomms10111

Wang, W., Sukamtoh, E., Xiao, H., and Zhang, G. (2015). Curcumin inhibits lymphangiogenesis in vitro and in vivo. Mol. Nutr. Food Res. 59 (12), 23452354. doi: 10.1002/mnfr.201500399

Wang, T., Chen, Y., Li, J. L., Wang, Y., Liang, Q., Xu, H., et al. (2017). Study on alleviating joint swelling by promoting lymphatic drainage and lymphangion genesis by Fangji Huangqi Decoction. China J. Tradit. Chin. Med. Pharm. 32 (05), 1961-1965. doi: CNKI:SUN:BXYY.0.2017-05-016.

Wen, J., Fu, A. F., Chen, L. J., Xie, X. J., Yang, G. L., Chen, X. C., et al. (2009). Liposomal honokiol inhibits VEGF-D-induced lymphangiogenesis and metastasis in xenograft tumor model. Int. J. Cancer 124 (11), 2709-2718. doi: 10.1002/ ijc. 24244

Yan, B., Zhang, Y. C., Shi, J., Wei, P. K., and Qin, Z. F. (2014). $\beta$-Elemene inhibits lymphangiogenesis by regulating the VEGF-C/VEGFR-3 signaling in gastric cancer cells xenografted nude mice. China J. Tradit. Chin. Med. Pharm. 29 (03), 907-910. (In Chinese)

Yu, J., Mao, L., Guan, L., Zhang, Y., and Zhao, J. (2016). Ginsenoside Rg1 enhances lymphatic transport of intrapulmonary silica via VEGF-C/VEGFR-3 signaling in silicotic rats. Biochem. Biophys. Res. Commun. 472 (1), 182-188. doi: 10.1016/ j.bbrc.2016.02.091

Yuan, X., Chen, Y., Li, X., Zhang, G., Jin, D., Zhao, H., et al. (2015). Norcantharidin inhibits lymphangiogenesis by downregulating the expression of VEGF-C and VEGF-D in human dermal lymphatic endothelial cells in vitro. Pharmacology 95 (1-2), 1-9. doi: 10.1159/000362418
Yurugi-Kobayashi, T., Itoh, H., Schroeder, T., Nakano, A., Narazaki, G., Kita, F., et al. (2006). Adrenomedullin/cyclic AMP pathway induces Notch activation and differentiation of arterial endothelial cells from vascular progenitors. Arterioscler. Thromb. Vasc. Biol. 26 (9), 1977-1984. doi: 10.1161/ 01.ATV.0000234978.10658.41

Zhang, F. C., Zhang, K. Y., Jia, Z. Y., Cao, M. H., and Li, Z. X. (2011). Experimental Study of Gecko Lyophilized Powder Inhibiting Tumor Neovascularization. Hebei Tradit. Chin. Med. 33 (9), 1383-1384. (In Chinese, doi: CNKI:SUN: HBZY.0.2011-09-061.

Zhang, J. T., Fan, Y. Z., Chen, C. Q., Zhao, Z. M., and Sun, W. (2012). Norcantharidin: a potential antiangiogenic agent for gallbladder cancers in vitro and in vivo. Int. J. Oncol. 40 (5), 1501-1514. doi: 10.3892/ijo.2011.1314

Zhang, N., Xie, F., Gao, W., Yu, S., Qiu, L., Lin, W., et al. (2015). Expression of hepatocyte growth factor and c-Met in non-small-cell lung cancer and association with lymphangiogenesis. Mol. Med. Rep. 11 (4), 2797-2804. doi: 10.3892/mmr.2014.3071

Zhou, X. M., Wang, D., He, H. L., Tang, J., Wu, J., Xu, L., et al. (2017). Bone Marrow Derived Mesenchymal Stem Cells Involve in the Lymphangiogenesis of Lung Cancer and Jinfukang Inhibits the Involvement In Vivo. J. Cancer 8 (10), 1786-1794. doi: 10.7150/jca.17859

Conflict of Interest: The authors declare that the research was conducted in the absence of any commercial or financial relationships that could be construed as a potential conflict of interest.

Copyright (c) 2020 Peng, Dong, Fan, Cao, Wu, Wang, Zhou, Li, Zhao and Wang. This is an open-access article distributed under the terms of the Creative Commons Attribution License (CC BY). The use, distribution or reproduction in other forums is permitted, provided the original author(s) and the copyright owner(s) are credited and that the original publication in this journal is cited, in accordance with accepted academic practice. No use, distribution or reproduction is permitted which does not comply with these terms. 